\title{
Trade credit: Elusive insurance of firm growth
}

Citation for published version (APA):

Bams, D., Bos, J., \& Pisa, M. (2016). Trade credit: Elusive insurance of firm growth. Maastricht University, Graduate School of Business and Economics. GSBE Research Memoranda No. 029 https://doi.org/10.26481/umagsb.2016029

Document status and date:

Published: 01/01/2016

DOI:

10.26481/umagsb.2016029

Document Version:

Publisher's PDF, also known as Version of record

\section{Please check the document version of this publication:}

- A submitted manuscript is the version of the article upon submission and before peer-review. There can be important differences between the submitted version and the official published version of record.

People interested in the research are advised to contact the author for the final version of the publication, or visit the DOI to the publisher's website.

- The final author version and the galley proof are versions of the publication after peer review.

- The final published version features the final layout of the paper including the volume, issue and page numbers.

Link to publication

\footnotetext{
General rights rights.

- You may freely distribute the URL identifying the publication in the public portal. please follow below link for the End User Agreement:

www.umlib.nl/taverne-license

Take down policy

If you believe that this document breaches copyright please contact us at:

repository@maastrichtuniversity.nl

providing details and we will investigate your claim.
}

Copyright and moral rights for the publications made accessible in the public portal are retained by the authors and/or other copyright owners and it is a condition of accessing publications that users recognise and abide by the legal requirements associated with these

- Users may download and print one copy of any publication from the public portal for the purpose of private study or research.

- You may not further distribute the material or use it for any profit-making activity or commercial gain

If the publication is distributed under the terms of Article $25 \mathrm{fa}$ of the Dutch Copyright Act, indicated by the "Taverne" license above, 


\section{Maastricht University}

Dennis Bams, Jaap Bos, Magda Pisa

Trade credit: Elusive insurance of firm growth

$\mathrm{RM} / 16 / 029$

\section{GSBE}

Maastricht University School of Business and Economics

Graduate School of Business and Economics

P.O Box 616

NL- 6200 MD Maastricht

The Netherlands 


\title{
Trade credit: Elusive insurance of firm growth
}

\author{
DENNIS BAMS, JAAP BOS and MAGDALENA PISA*
}

October 7, 2016

\begin{abstract}
Firms depend heavily on trade credit. This paper introduces a trade credit network into a structural model of the economy. In an empirical analysis of the model, we find that trade credit is an elusive insurance: as long as a firm is financially unconstrained and times are good, more trade credit enhances sales stability and insures against shocks to the firm's suppliers. However, if a firm becomes financially constrained or times are bad, trade credit fails to insure against supplier shocks. Moreover, if the firm is low on cash, trade credit propagates shocks from a supplier to its customer.
\end{abstract}

\section{Introduction}

The importance of trade credit is indisputable. As reported by Williams (2008) and recounted in Barrot (2016), about 90\% of global merchandise is purchased on trade credit. But can trade credit insure firms against shocks occurring elsewhere in the economy or does it propagate those shocks? Cuñat (2007) argues that trade credit mitigates shocks and provides insurance, by transferring part of the risk borne by a customer onto its suppliers.

\footnotetext{
${ }^{*}$ Bams and Bos are at Maastricht University, Pisa is at WHU - Otto Beisheim School of Management. The authors thank Dimitris Pongas for support and helpful discussions and Yakov Amihud, Gabriela Contreras, Matteo Millone, the participants at the Tenth Annual Risk Management Conference at NUS in Singapore, the 2016 FMA European Conference in Helsinki, the 33rd International Conference of the French Finance Association in Liège, the XIV European Workshop on Efficiency and Productivity Analysis in Helsinki, the 2016 RWTH finance seminar in Aachen and the 2015 CREDIT Conference in Venice for useful comments. The present project is supported by the National Research Fund, Luxembourg.
}

JEL classification: E32, G32, L14.

Keywords: Trade credit, Insurance, Credit chains, Spillover effects. 
Jacobson and von Schedvin (2015) and Barrot (2016), however, focus on the aggravating aspects of trade credit, including contagion and counterparty risk. This paper reconciles both views and finds that trade credit is an elusive insurance: as long as a firm is financially unconstrained, more trade credit enhances sales stability and insures against shocks from a firm's suppliers. As soon as the firm becomes financially constrained, trade credit's stabilizing abilities come to an end and trade credit itself may serve as a mechanism propagating supplier shocks downstream the production network.

With this paper, we contribute to the understanding of trade credit in three ways. First, we propose a model of a multi-sector economy in which we introduce trade credit into the literature on production relationships and highlight the combined role of trade credit and production relationships in connecting firm-level shocks. We investigate a mechanism described by Long and Plosser (1983) and Acemoglu et al. (2012), in which a business cycle arises as a result of an asymmetric production relationship. We then build on Raddatz (2010) and Balke (2000) to augment this mechanism with a trade credit dimension.

Second, this study empirically demonstrates that in many circumstances trade credit indeed serves as an insurance against shocks occurring upstream in a firm's network. When empirically testing the model of Acemoglu et al. (2012), augmented with a trade credit network, we find that on average trade credit lowers the impact of a supplier shock by 20$25 \%$ and thus considerably stabilizes a firm's sales. We attribute this insurance role of trade credit to the switching cost theory. According to Cuñat (2007), trade credit is typically a result of switching costs associated with losing a production partner. Many of the goods sold on trade credit are likely not to be homogenous nor standardized (Giannetti, Burkart, and Ellingsen, 2011), making them difficult to resell to other firms (Burkart and Ellingsen, 2004). This in turn makes firms less flexible in changing their production partners. It also strengthens the customer-supplier relationship. In the latter case, if a supplier receives a negative productivity shock, it prefers to deliver the goods first to a customer with which it has a more significant trade credit relationship. But not only negative shocks are insured against. A positive productivity shock is dampened as well due to the contractual agreement 
between both parties.

Lastly, we contribute to a more thorough understanding of the dark side of trade credit. Our empirical tests reveal that the insurance properties of trade credit prove elusive when they are most urgently needed: during recessions, for firms with low cash reserves and for firms that are heavily dependent on external finance. In their seminal work, Kiyotaki and Moore $(1997,2002)$ already postulate that, in the presence of trade credit, financially constrained firms co-move with their production partners. Recent empirical evidence further corroborates the causes of this dark side of trade credit. Barrot (2016) document that long payment terms of trade credit are associated with liquidity risk which drives credit constrained firms more often to distress. Petersen and Rajan (1997), argue that credit constrained customers rely on the liquidity provided by their supplier, which then, we argue, exposes them to fluctuations in the supplier's performance. We provide empirical evidence that although generally unobservable, the dark side of trade credit resurfaces once a firm becomes financially constrained.

To corroborate these findings, we provide evidence that the elusive nature of the insurance provided by trade credit is unlikely to come from common shocks. By distinguishing firms that operate in the same region or the same industry, we can exploit cross-sectional variation at the regional or industry level to more cleanly identify the relationship between trade credit and sales growth.

Our results rely on the features of a Cobb-Douglass economy. The Cobb-Douglass representation of technology and utility implies that shocks can propagate downstream, i.e. by changing costs of customers of the firm affected by the shock. But the same representation also means that the shocks do not propagate upstream as explained in Shea (2002) and Acemoglu et al. (2012). It is a consequence of two competing effects that are assumed to cancel out: (1) demand for inputs rises following a raise in output price, but at the same time (2) demand for inputs falls following a fall in the production output. Although commonly accepted in the literature, we evaluate this assumption. To test if our results are affected by an upstream propagation of shocks, we distinguish firms that are large, strategic and have 
heavily reliant suppliers. If such a strategic customer grows at a high rate, under upstream propagation its suppliers should have a positive boost in their sales and be more likely to grow at a higher rate. In that case, the sub-sample of strategic customers should show a higher correlation between a customer and its suppliers and lower downstream propagation. However, we find no evidence of this reverse causality, suggesting that the downstream propagation of shocks from suppliers to customers prevails, as proposed in the economic model.

The remainder of this paper continues as follows. In Section II, we introduce a trade credit relationship into the model of Acemoglu et al. (2012). Section III describes our empirical approach, and in Section IV we detail our data. Section V contains our empirical analysis, before we conclude in Section VI.

\section{Theory}

In this section, we introduce a structural model with explicit production and trade credit relationships. We consider a static version of the multi-sector economy of Long and Plosser (1983), where the economy is populated by a representative household with given tastes and production possibilities. We assume the household has a Cobb-Douglas utility function over $n$ distinct commodities produced by $n$ distinct firms:

$$
u\left(c_{1}, c_{2}, \ldots, c_{n}\right)=\prod_{i=1}^{n}\left(c_{i}\right)^{1 / n},
$$

where $c_{i}$ is the consumption of firms $i$ 's commodity. The household is endowed with one unit of labor, which is supplied inelastically. At the beginning of each period, the household decides about its consumption as well as commodity and labor inputs to various production transformations to be completed in this period. Those choices are constrained by the availability of labor and inputs. As we assume the commodities to be perishable, only the amount produced in a given period can be used as an input in the production process in that particular period. 
During the period, the production transformation is subject to various exogenous shocks that alter the production possibilities and ultimately determine the amount of commodities available for consumption or as production input. These shocks affect the household either through the production relationship or through the trade credit relationship. Following Raddatz (2010), we allow a firm $i$ to buy a fraction $\beta_{i}$ of its input on trade credit. This is where we extend the model specification of Acemoglu et al. (2012). In particular, a fraction $\left(1-\beta_{i}\right)$ is paid up-front or on delivery while payment of the fraction $\beta_{i}$ is due at a later date and shows up in the customer's balance sheet as an account payable.

The trade credit dimension is novel to the model and it can affect the production possibilities of the firm. However, whether or not a firm purchases inputs on trade credit, does not otherwise affect the way in which it transforms inputs into output. Specifically, $n$ firms buy intermediary inputs from one another and firm $i$ produces a quantity $x_{i}$ of commodity $i$ according to a Cobb-Douglas technology with constant returns to scale:

$$
\begin{aligned}
x_{i} & =z_{i}^{\alpha} l_{i}^{\alpha} \prod_{j=1}^{n} x_{i j}^{(1-\alpha)\left(1-\beta_{i}\right) w_{i j}} x_{i j}^{(1-\alpha)(1+\eta) \beta_{i} w_{i j}} \\
& =z_{i}^{\alpha} l_{i}^{\alpha} \prod_{j=1}^{n} x_{i j}^{(1-\alpha)\left(1+\eta \beta_{i}\right) w_{i j}},
\end{aligned}
$$

where $z_{i}=\exp \left(\xi_{i}\right)$ is firm $i$ 's specific productivity shock distributed independently across firms, $l_{i}$ is the amount of labor hired by firm $i, x_{i j}$ is the amount of commodity $j$ used in the production process of commodity $i$ and parameter $\alpha$ is the output elasticity of labor in the economy. Next, the parameter $w_{i j} \geq 0$ denotes an element in the $(n \times n)$ input-output matrix $W$ that measures the amount spent on input $j$ per dollar of production of firm $i$. The column sums of $W$ reflect the importance of a firm as a supplier to other firms' production processes. At the firm level, the diagonal of $W$ is equal to zeroes since a firm does not deliver to itself.

The impact of trade credit on a firm's production possibilities is governed by parameter $\eta$. If $\eta$ assumes a value greater than zero, the inputs purchased on trade credit have greater output elasticity than the inputs purchased directly. In the reverse situation, if $\eta$ assumes a 
value less than zero, the inputs purchased directly have greater productivity. As explained in Appendix A, maintaining the assumption of constant returns to scale, in line with Acemoglu et al. (2012), ensures that the rate at which labor can be substituted for an intermediate good $x_{i j}$ is not affected by trade credit.

The fact that a firm uses intermediate inputs from other firms is a basis for interconnectedness in this economy. The Cobb-Douglass representation of technology and utility implies that the transmission of firm-level shocks occurs only downstream through the input-output matrix from supplier to customers. In general, for a non-Cobb-Douglas production technology upstream propagation is possible and depends on two competing effects. For example, a negative shock to a firm has two effects on its demand for inputs. The first effect is an increase in the price of the firm's output, which in turn increases the firm's demand for intermediate inputs. At the same time, the second effect decreases the quantity produced, which in turn decreases the firm's demand for intermediate inputs. As shown before by Acemoglu et al. (2012) and Shea (2002), for a Cobb-Douglas production technology like the one employed here, these two effects cancel out, thus excluding the possibility of upstream shock transmission.

Let $y$ denote the logarithm of real value added, also referred to as aggregate output. In Appendix B we show that the evolution of aggregate output follows:

$$
y=\mu+u^{\prime} \xi
$$

where $\mu$ is a constant that depends on model parameters only, $\xi$ is a $(n \times 1)$ vector of firmlevel input shocks and $u$ is a $(n \times 1)$ vector that governs the transmission of firm-level shocks in the economy. Equation (3) shows how fluctuations in aggregate output originate from disturbances to a firm's production possibilities. Those disturbances are weighted by the importance of the production relationship and the trade credit relationship, reflected by the 
vector $u$. It holds that:

$$
u=\frac{\alpha}{n}\left[I-(1-\alpha)(1+\eta B) W^{\prime}\right]^{-1} \mathbf{1}
$$

where $B=\operatorname{diag}\left(\beta_{1}, \ldots, \beta_{n}\right)$ and $\mathbf{1}$ is a $(n \times 1)$ vector of ones. Similarly to Raddatz (2010), the vector $u$ reflects the impact of both the production relationship, through the inputoutput matrix $W$, and the trade credit relationship, through $B$, in transmitting the firmlevel shocks. In particular, the parameter $\eta$ is a measure for the importance of the trade credit relationship. If $\eta$ assumes a value greater than zero it amplifies the transmission mechanism that occurs due to the direct production links. Values lower than zero decrease this transmission mechanism. If trade credit has no effect on the transmission of firm-level shocks, the parameter $\eta$ assumes a value of zero and the above equation simplifies to the influence vector of Acemoglu et al. (2012) given by:

$$
v=\frac{\alpha}{n}\left[I-(1-\alpha) W^{\prime}\right]^{-1} \mathbf{1}
$$

In the latter case, fluctuations in aggregate output due to firm-level shocks are only transmitted through the production relationship.

We further disentangle the transmission effects by taking a first order Taylor approximation of $u$ around $\eta=0$ (see Appendix C). It follows that:

$$
\begin{aligned}
u & \approx \frac{\alpha}{n}\left[I-(1-\alpha) W^{\prime}\right]^{-1} \mathbf{1}+\eta \frac{\alpha}{n}(1-\alpha)\left[I-(1-\alpha) W^{\prime}\right]^{-1} B W^{\prime}\left[I-(1-\alpha) W^{\prime}\right]^{-1} \mathbf{1} \\
& =v+\eta(1-\alpha)\left[I-(1-\alpha) W^{\prime}\right]^{-1} B W^{\prime} v .
\end{aligned}
$$

The first term in equation (6) represents the production relationship, and the second term shows the effect of the trade credit relationship. In particular, in case of negative values for $\eta$, the larger the share of inputs provided on trade credit $(B)$, the smaller the transmission of input shocks. In this case, trade credit acts as insurance against supplier-level input shocks. Positive values of $\eta$ give greater weight to supplier shocks, and therefore magnify 
supplier-level input shocks felt by customer firms.

For a single firm $i$, equations (3) and (6) imply the following relationship to input shocks (see Appendix D for full derivation):

$$
y_{i}=\mu_{i}+\frac{\alpha}{n} \sum_{j=1}^{n} D_{i j} \xi_{j}+\eta \beta_{i} \frac{\alpha(1-\alpha)}{n} \sum_{j=1}^{n}\left[D W^{\prime} D\right]_{i j} \xi_{j}
$$

where $D=\left[I_{n}-(1-\alpha) W^{\prime}\right]^{-1}$ and $I_{n}$ is the $(n \times n)$ identity matrix. Equation $(7)$ is the basis for the empirical specifications that we propose in the next section.

\section{Empirical approach}

In this section, we explain our estimation procedure, after introducing our key variables, starting with firm activity. Various empirical proxies for firm activity have been proposed in the literature. These proxies include the value added per worker (Gabaix, 2011), total factor productivity (Carvalho and Gabaix, 2013)) and employment (Moscarini and PostelVinay, 2012). Since trade credit is measured as a proportion of sales supplied with a deferred payment, we follow di Giovanni, Levchenko, and Mejean (2014) and represent firm activity as follows:

$$
y_{i} \equiv \ln \left(\text { sales }_{i}\right)
$$

Our interest is in particular with the transmission mechanism of shocks originating at a supplier's production processes. To that end we quantify firm-level shocks $\xi_{i}$ in a manner similar to Gabaix (2011), that is we set the firm-level shock to be a deviation from a particular benchmark. Similar to Gabaix (2011), we set this benchmark to be equal to the average of $\ln \left(\right.$ sales $\left._{i}\right)$ over all firms in the economy, denoted with $\bar{y}_{E}$. The firm-level input shock follows as the difference between a firm's sales and the average sales in the economy:

$$
\hat{\xi}_{i}=y_{i}-\bar{y}_{E}
$$

Manski (1993) notices a reflection problem: firms' activity might be volatile due to com- 
mon shocks, but not necessarily vice versa. To address this reflection problem, we use various measures for the firm-level input shocks. Alternative specifications include deviations relative to developments in an industry or in a region. The industry benchmark $\left(\bar{y}_{I}\right)$ is given by the average of $\ln \left(\right.$ sales $\left._{i}\right)$ over firms in a particular industry, based on the four digit SIC industry classification. The region benchmark is given by the average of $\ln \left(\right.$ sales $\left._{i}\right)$ over firms in a region where the region is defined by the state $\left(\bar{y}_{S}\right)$ or county $\left(\bar{y}_{C}\right)$ of a firm's headquarter. Those specifications work under the assumption that firms respond to common shocks with the same sensitivity.

We follow the literature (Gabaix (2011), and di Giovanni, Levchenko, and Mejean (2014)) and look into the growth rate of a firm's activity and in particular into the growth rate of sales. Define the growth rate of sales for firm $i$ as $g_{i}=\Delta y_{i}$, which is the difference in log sales from one year to the other. Also, define the difference in shock to firm $i$ as $e_{i}=\Delta \xi_{i}$, which is the change in log sales from one year to the other relative to the change in their benchmark. The resulting empirical relationship follows by taking first differences in equation (7):

$$
g_{i}=\phi\left\{\sum_{j=1}^{n}\left(\frac{\alpha}{n} D_{i j}\right) e_{j}\right\}+\eta\left\{\sum_{j=1}^{n} \beta_{i} \frac{\alpha(1-\alpha)}{n}\left[D W^{\prime} D\right]_{i j} e_{j}\right\}+\varepsilon_{i} \quad i=1, \ldots, n
$$

The first term in equation (10), which we refer to as the production relationship exposure, depicts the relationship between a customer's sales growth and production in the absence of trade credit, or if trade credit does not matter for transmission of firm-level shocks. It is a weighted sum of firm-level suppliers' shocks, where the weights depend on the relative importance of the suppliers for a customer's production process. A parameter $\phi$ has been included in this first term. From the theoretical model in equation (7) we expect the estimate of parameter $\phi$ to be equal to one.

The second term in equation (10), which we refer to as trade credit exposure, is a weighted sum of firm-level supplier input shocks with weights determined by a supplier's importance in delivering inputs and its position as a trade credit provider. In the second term, the parameter $\eta$ indicates the importance of the trade credit relationship in the transmission of 
firm-level shocks. Positive values of $\eta$ amplify the shocks to the production process, while negative values insure against them. If $\eta=0$, the trade credit relationship is irrelevant for the transmission of shocks between firms.

Equation (10) includes parameters $\alpha, \beta_{i}, W$ and $D$. In the next section we will propose proxies for these parameters. The remaining parameters $\phi$ and $\eta$ are the focus of this study, and will be estimated by minimizing the sum of squared residuals $\left(\sum_{i=1}^{n} \varepsilon_{i}^{2}\right)$. In particular, we investigate the role of trade credit in transmitting firm-level shocks. In normal times, we expect the estimate of $\eta$ to be negative and significantly associated with customers' sales growth. However, during recessions or in case of financially constrained firms, we expect $\eta$ to be zero or positive as trade credit may amplify shocks to customers, similar to Kiyotaki and Moore (1997).

In the empirical analysis, we also verify that the correlation between shocks to suppliers and the sales growth of their customer is not driven by either a common shock or by a reverse causal relationship from customer to supplier.

In order to test that, we first evaluate if shocks to suppliers are spuriously correlated with a customer's sales growth as a result of exposure to common shocks. We address this problem by the way in which shocks to suppliers are computed: we disentangle the common component from the firm-level component by demeaning suppliers' growth rate on the economy, industry, state and county level. As a result, suppliers' shocks are equivalent to suppliers' excess growth relative to an economy, industry, state and county benchmark. The excess growth is meant to be firm-specific and represents the idiosyncratic component of their sales growth.

Moreover, we estimate a specification with time-varying industry and state fixed effects to capture common shocks which might have affected firms in one industry or state disproportionally to the rest of the economy. To illustrate this consider a supplier linked to two customers A and B by the same kind of production process relationship and a different trade credit relationship. Customer A operates in the same four digit SIC industry as the supplier and receives low trade credit. In contrast, customer B operates in another industry and 
receives high trade credit. Now, if a positive common shock affects the industry in which the supplier and customer A operate, the supplier experiences a positive excess growth shock relative to the economy benchmark and customer A grows at a higher rate. On the other hand, customer B does not reap the benefits of this positive common shock and grows at a lower rate. The lower growth rate of customer B may seem to be related to the higher trade credit ratio while in fact it is due to missing out on the positive common shock. If for some reason customers tend to have a lower trade credit relationship with their suppliers in the same industry or in the same region, the effect of common shocks can be controlled for by time varying industry effects or time varying region fixed effects. ${ }^{1}$

To address the second issue, we notice that a reverse causal relationship would imply a transmission mechanism that works from customer to supplier, where a high growth rate of a customer would trigger a positive shock to its supplier, but less so with an increase in trade credit. Cases where a development in customer growth is followed by a response in its suppliers' excess growth should intuitively involve customers that are important and strategic to their suppliers. Purchases from those strategic customers correspond to a high share of suppliers' sales and swings in customers' demand are more likely to be reflected in changes in the growth of their suppliers. By focusing on a sub-sample of customers that are strategic to their suppliers, we allow for the reverse causal relationship to be revealed. In this particular sub-sample, a reverse causal relationship would manifest itself by an increased correlation. In the results section we will explicitly investigate this case.

\section{Data}

At the heart of our data is a list of customer-supplier pairs. Under the Statement of Financial Accounting Standards (SFAS), rule no. 131, a firm needs to disclose certain information on its operating segments. In particular, a firm is required to reveal the identity of its major customers that purchase above $10 \%$ of its sales. We use a sample of such customer-supplier

\footnotetext{
${ }^{1}$ This can be the case, for example, if firms use trade credit to deal with information asymmetry of their production partners by screening firms in a different industry rather than those operating in the same industry (Smith, 1987).
} 
pairs identified by Cohen and Frazzini (2008) based on Compustat Segments information. We can identify each firm in this sample based on its CRSP permno. This allows us to match the customer-supplier pairs identified by Cohen and Frazzini (2008) with CRSP-Compustat's balance sheet information.

In particular, we focus our analysis on customer-supplier pairs in which customers operate in manufacturing, transportation, wholesale and retail trade (SIC code 2000-5999). The customer-supplier pairs are required to have a match to Compustat balance sheet information, non-missing values of assets, non-missing values of cost of goods sold, and non-missing values of sales in two consecutive years. The final set contains 4,785 unique customer-year observations. Each of these observations is connected on average to 2.71 suppliers with a total of 12,985 unique customer-supplier-year observations over the years 1980 to 2004 .

The customers reported in Panel A of Table I tend to be larger than the suppliers in Panel D. This discrepancy is partially due to the way the customer-supplier pairs are identified. The customers reported in Compustat Segments, and therefore in the Cohen and Frazzini (2008) sample, are those that correspond to at least $10 \%$ of sales. Those firms are inclined to be larger with assets on average almost 13 times higher and sales 14 times higher than the sample of suppliers. During the entire sample period, on average both customers and suppliers experience a positive sales growth rate $(g)$ illustrated in Figure 1. For most of the time it stays positive with a short episode of negative growth in 2002 .

In our analysis, we approximate three elements of equation (10): the weights attributed to suppliers that define the production relationship, the weights attributed to suppliers that define the trade credit relationship and finally the supplier shocks.

To compute the weights defining the production relationship, we approximate parameter $w_{i j}$ and parameter $\alpha$. Parameter $w_{i j}$ is said to capture the amount spent on input $j$ per dollar of production of firm $i$. On a firm level, we approximate it by the ratio of sales from supplier (firm $j$ ) to customer (firm $i$ ) over a customer's cost of goods sold (Compustat item cogs). It represents the amount customer $i$ spent on inputs from supplier $j$ per dollar amount of its production cost. On average, about $4.2 \%$ of a customer's input comes from one of its 
suppliers. The labor income share denoted by $\alpha$ is assumed to be constant over the whole economy and takes a value of 0.61 . We compute it from the OECD data on Unit Labor Costs as the average of the Labor Income Share (Real ULC) between 1995 and 2004, the period for which it is available.

To compute the weights defining the trade credit relationship, we compute the share of trade credit received by a customer $\left(\beta_{i}\right)$. To this end we follow Raddatz (2010) and measure $\beta_{i}$ as the ratio of a customer's accounts payable (Compustat item ap) over its cost of goods sold (Compustat item cogs). It depicts the proportion of purchased inputs with deferred payment and typically reflects the share of goods that the customer purchased on trade credit. Since we do not observe the share of trade credit contributed by individual suppliers, we assume this share to be equal across all suppliers delivering to a given customer. In our sample, customers buy about $15 \%$ of their inputs on trade credit. Their dependence on trade credit is comparable with the U.S. firms in Raddatz (2010), which finance about $13 \%$ of inputs with trade credit. ${ }^{2}$ Figure 2 illustrates the time series development of the proportion of inputs delivered on trade credit. Over the sample period of 25 years there is an increase in the amount of trade credit used with a slight drop during recessions.

Lastly, we quantify supplier shocks $e_{j}$ as a deviation from a benchmark. The benchmark is given by an average $\ln ($ sales) growth among a group of firms to which the supplier belongs. We compute the economy $\ln ($ sales $)$ growth $\left(\bar{g}_{E}\right)$ as the average growth among all the firms in the Compustat universe. Next, we categorize firms into industries based on the four digit SIC code to compute the industry benchmark as an average of sales growth over firms in the same industry. We repeat this exercise and compute the state benchmark as an average of $\ln$ (sales) growth over firms in the same U.S. state and the county benchmark as an average of sales growth over all firms operating in the same county.

Figure 3 illustrates the time series evolution of the supplier shocks estimated relative to economy, industry, state and county benchmark. There is a considerable commonality between the supplier shocks and the average sales growth rate among suppliers. In general,

\footnotetext{
${ }^{2}$ Raddatz's (2010) sample includes a universe of U.S. firms in Compustat over a similar time period.
} 
their behavior is closely related and both values co-move together. For example, during the NBER recessions, illustrated by the shaded areas, both the benchmark and the average sales of suppliers tend to drop considerably.

In Table II we examine the correlations between customer and supplier sales growth, and the benchmarks. The correlations are computed from yearly observations pooled across all the customer and supplier firms. At the bottom of column (2) we report the correlations between supplier sales growth and the shocks to customer sales growth using different benchmarks. The high correlation indicates that there is a considerable commonality between disturbances to customer sales growth and supplier sales growth.

\section{Empirical results}

Our empirical analysis consists of four steps. First, we establish whether shocks to suppliers are indeed transmitted through the customer-supplier network and find out how different elements of that customer-supplier network - production relationship and trade credit - contribute to the direction and magnitude of that transmission mechanism. Next, we investigate how common shocks affect the transmission mechanism of both elements. Third, we verify the robustness of the distinction between these two elements. Finally, we delve deeper into the role of trade credit as an elusive insurance mechanism.

\section{A Shock transmission through a production relationship}

From our theoretical model in Section II, we learn that, in general, the use of credit in the customer-supplier relationship may work as insurance against shocks to suppliers and may reduce disturbances to customers' sales. Whether those shocks to suppliers are transmitted through the customer-supplier network and what is the role of production relationship and trade credit relationship, is answered in Table III.

Based on the economic model, we hypothesize the relationship between sales growth and production relationship $(\phi)$ to be equal to one, as the change to customers' sales should be greater with a greater shock to its crucial suppliers of inputs. Likewise, we hypothesize 
the relationship between customers' sales growth and the trade credit relationship $(\eta)$ to be negative since trade credit is expected to act as insurance against supplier shocks.

Column (1) of Table III allows for a basic test of both hypotheses. Indeed, we find that production relationship propagates shocks from a supplier onto its customer with a value for $\phi$ that is not statistically different from one. Also, the use of trade credit reduces the severity of shocks and acts as an insurance. When we control for fixed effects in Column (2), both results appear to be robust.

Both effects are also economically sizable. Depending on the specification, in the absence of trade credit a one standard deviation positive (negative) shock to all suppliers increases (decreases) customer's sales growth by about $0.50 \%$. If trade credit accompanies that same production relationship the disturbance is lower and amounts to about $0.40 \%$. In other words, a customer experiences about 20-25\% lower disruption to its sales from a shock to its supplier if trade credit exists next to a production relationship. ${ }^{3}$

\section{$B$ The transmission and common shocks}

In our analysis so far, we have implicitly assumed that a shock affects a single supplier, and has no direct impact on others other than through production and trade credit relationships. In the following, we deal with the possibility of same shock striking multiple firms. In particular, we address the possibility of a common shock to suppliers and customers in the same industry or state.

Imagine a positive common shock to a given industry (or state) at a given point in time. Contrast one customer-supplier pair that operates in the affected industry with a second customer-supplier pair in which the customer operates in another industry. In the former case, the high correlation between the state of the customer and the state of its supplier could result from their exposure to the common shock rather than from a trade credit relationship. In the latter case, however, the customer is not directly exposed to the shock

\footnotetext{
${ }^{3}$ Note that our matrix of network is not exhaustive and we are missing the customer-supplier network that do not pass the $10 \%$ threshold to be reported in the Compustat Segments database. However, we believe that in the limit those connections could be approximated by the industry or state or county benchmark. In turn this leaves those connections with no impact on the analysis as their shocks are equal to zero.
} 
and any correlation between its state and that of its supplier is more likely to come from trade credit usage in the absence of exposure to the common shock.

We therefore isolate the effect of common shocks from the effects of the production relationship and the trade credit relationship by means of time varying industry and state fixed effects. Results are reported in columns (3) and (4) of Table III and appear robust to common shocks. Customers are affected more by shocks to crucial suppliers of inputs but less so if trade credit accompanies the production relationship. These results are in line with Gao (2014), who shows that in a tight network of customer-supplier relationships, a liquidity shock to one firm triggers a flow of liquidity from other parts of the network. One example is Bosch that supported its liquidity-constrained suppliers by offering them forward payments and reimbursement of raw materials. In this example behavior of Bosch comes from a tight customer-supplier relationship and aims at buffering the effects of shocks to its suppliers.

Alternatively in Table VII, Table VIII and Table IX we specify firm-level shocks as deviation from an industry, state or county benchmark. Those specifications should disentangle any common shock on industry, state or county level from a supplier-level shock. In Panel A of each of these tables we repeat our analysis and find robust evidence of trade credit insurance abilities.

\section{Distinguishing between trade credit and production relationship}

Until now, we have established that a customer-supplier network, related to production and to trade credit, affects the transmission of shocks. Now, we put more effort into distinguishing between the strength of the production relationship and the trade credit relationship, respectively.

We start in Column (1) of Table IV by repeating our analysis for a sub-sample of firms with very low shares of trade credit. For these firms, the production process forms the base for their interconnections. Hence, we expect to find that the trade credit relationship has a negligible effect on sales growth for this sub-sample. Indeed, our results show that for this sub-sample the production relationship is the only channel through which shocks are 
transmitted.

In Column (2) of Table IV, we take the above examination one step further and drop the trade credit relationship from our analysis. As a result, we effectively estimate the Acemoglu et al. (2012) model, which assumes that only the production relationship can propagate shocks from suppliers onto customers. If trade credit has an insurance effect, we expect to understate the size of the production relationship in this estimation. Indeed, that is what we find.

Next, in Column (3) we provide a more direct comparison of our results with the predictions from the Acemoglu et al. (2012) model, by constraining the coefficient of the production relationship at its theoretical value, equal to one. From the Table, we observe that the economic magnitude of the trade credit relationship remains unchanged.

Finally, in Column (4) we focus on a sub-sample of strategic customers, who are of particular importance for their suppliers. Doing so, allows us to address possible reverse causality issues. After all, a change in a firm's state can originate on the supplier side (downstream propagation) or on the customer side (upstream propagation). In the economic model we allow for downstream propagation, not upstream propagation. In the latter case, if a strategic customer grows at a high rate, as a consequence its supplier is expected to have a positive boost in its sales and is likely to grow at a rate higher than the rest of the economy. Thus, focusing on a sub-sample of strategic customers should increase the scope of upstream propagation while diminishing the downstream propagation. This provides us with a perfect testing ground of possible reverse causality. For each customer, we find its minimum share in suppliers' sales. Next, we rank all customers according to that minimum. Results in Column (4) show that the top decile most strategic customers do not exhibit a higher correlation with their suppliers' excess growth, confirming that our analysis primarily captures the downstream propagation of shocks from suppliers onto their customers. 


\section{Trade credit as an elusive insurance}

In the final part of our analysis, we focus in more detail on the role of trade credit. Thus far, we have found that both the production relationship and the trade credit relationship play an important role in the downstream transmission of shocks. On the face of it, trade credit appears to act as an insurance against disruptions caused by supplier shocks: after a negative shock to its supplier, a customer grows at a higher rate than it would have grown had it not received any trade credit.

Here, we study how reliable the implicit insurance offered by trade credit is in practice by zooming in on those customers that are indeed financially constrained. Of course it is possible that suppliers end trade credit once a customer becomes financially constrained. However, Panels B and C of Table I provide evidence to the contrary: we do not observe a significant drop in trade credit provision during recessions. Therefore, we re-estimate equation (10) and include a measure of how financially constrained a customer is, which we then also interact with the trade credit relationship. If trade credit is a durable and reliable insurance against shocks from production partners, the interaction term should be negative and significant or at least insignificant.

Table V contains estimation results for three different measures of how financially constrained the customer is. The simplest measure is included in Column (1), in which we concentrate on recessions, when a large number of firms is expected to be financially constrained. As it turns out, during recessions trade credit does not insure customers against shocks propagated from their suppliers. Firms with high trade credit are systematically less able to reap the benefits of positive developments in good times and in bad times are in general less resilient to shocks propagating from their suppliers.

We continue this line of thought in Column (2), where we define firms to be financially constrained if in a given year their cash reserves relative to their sales are in the bottom 5 percentile. For such cash-poor firms, we observe a contagion effect similar to Kiyotaki and Moore (1997) where trade credit not only is a very poor insurance against shocks from suppliers but it also amplifies those shocks and further destabilizes customers' sales. 
In Column (3), we consider firms to be financially constrained following Rajan and Zingales (1998), who measure firms' dependence on external finance. ${ }^{4}$ Again, trade credit fails to provide insurance for the most vulnerable firms. For the top decile of most financially constrained firms, it does not matter if the firm is using trade credit or not: the shock to its supplier will hit it with the same strength.

As a final step, we challenge these results by once again controlling for common shocks and reverse causality. Table VI reports the results for recession times and the Rajan and Zingales (1998) measure of firm's dependence on external finance. In Columns (1) and (2), we include time varying fixed effects and control for the effect of common shocks. Our findings and the economic magnitude of the effects remains unchanged. Columns (3) and (4) tackle the issue of reverse causality by including an indicator which is equal to one if a customer has many heavily reliant suppliers, and zero otherwise. With no increase in correlation for those customers we find no evidence of reverse causality. Results are also robust to using an industry benchmark where shocks are computed as a deviation from the industry average (Table VII), to using a state benchmark in which suppliers shocks are computed as a deviation from the state average (Table VIII) and to using a county benchmark in which suppliers shocks are computed as a deviation from the county average (Table IX).

\section{Concluding remarks}

This paper finds that the transmission of shocks downstream the customer-supplier relationship process depends both on the strength of the production relationship between suppliers and customers and on the extent to which the former provide trade credit to the latter. Not accounting for the trade credit relationship results in an overestimation of the importance of the production relationship, since the trade credit relationship on average mitigates the impact of shocks.

Once we delve deeper into these findings, however, we find that trade credit is an elusive

\footnotetext{
${ }^{4}$ They use the ratio of capital expenditures (Compustat item capx) reduced by the sum of funds from operations (fopt), inventory (invch), accounts receivable (recch) and accounts payable (apalch) to capital expenditures.
} 
insurance against shocks from production partners. The insurance aspect of trade credit only works if customers do not need it, i.e., if they are not financially constrained. In unfavorable situations, trade credit further lowers sales stability and provides no insurance against shocks propagating downstream from suppliers. Our results are robust to common shocks and appear not to be affected by possible upstream propagation of shocks. Also, the results hold for a broad range of measures of how financially constrained a firm is.

The main takeaway from our analysis is that firms may overestimate the importance of trade credit. The latter can be seen as an important element of building a relationship between customers and suppliers, and reflects the trust that both parties have in that relationship. However, the economic value of trade credit is in fact lowest when customers may need it the most: when they are financially constrained and/or find themselves in a recession. 


\section{Appendix A Production function}

In order to assess relationship between the production function we use and the role of trade credit, we must start with the assumption of constant returns to scale. Imposing constant

returns to scale on the production function in equation (2), implies that: $\sum_{j} w_{i j}=\frac{1}{1+\eta \beta_{i}}$. We note, however, that the constant returns to scale assumption does not necessarily imply that the marginal rate of technical substitution (MRTS) between labor and an intermediate input $x_{i j}$ is constant. We start by simplifying notation on our production function:

$$
x_{i}=z_{i}^{\alpha} l_{i}^{\alpha} \prod_{j=1}^{n} x_{i j}^{\beta_{i}^{*}}
$$

noting that now $\beta_{i}^{*}=(1-\alpha)\left(1+\eta \beta_{i}\right) w_{i j}$ and $\alpha+\beta_{i}^{*}=1$ implies CRS. We can then derive the marginal productivity of labor, $M P_{l}$ :

$$
M P_{l}=\alpha z_{i}^{\alpha} l_{i}^{\alpha-1} \prod_{j=1}^{n} x_{i j}^{\beta_{i}^{*}}
$$

Likewise, the marginal productivity of an intermediate input, $M P_{x_{i j}}$ is:

$$
M P_{x_{i j}}=\beta_{i}^{*} z_{i}^{\alpha} l_{i}^{\alpha} \prod_{j=1}^{n} x_{i j}^{\beta_{i}^{*}-1}
$$

Hence:

$$
M R T S=\frac{M P_{l}}{M P_{x_{i j}}}=\frac{\alpha z_{i}^{\alpha} l_{i}^{\alpha-1} \prod_{j=1}^{n} x_{i j}^{\beta_{i}^{*}}}{\beta_{i}^{*} z_{i}^{\alpha} l_{i}^{\alpha} \prod_{j=1}^{n} x_{i j}^{\beta_{i}^{*}-1}}=\frac{\alpha l_{i}}{\left(1+\eta \beta_{i}\right)(1-\alpha) w_{i j} x_{i j}} .
$$

The CRS constraint that $\sum_{j} w_{i j}=\frac{1}{1+\eta \beta_{i}}$, then implies that:

$$
M R T S=\frac{\alpha l_{i}}{(1-\alpha) x_{i j}}
$$

Hence, our CRS constraint implies that the rate at which labor can be substituted for an intermediate good $x_{i j}$ is not affected by the trade credit. 


\section{Appendix B Competitive equilibrium}

We derive the competitive equilibrium by closely following Acemoglu et al. (2012). The competitive equilibrium is a set of commodity prices $p_{i}$, wage $h$ and consumption choices $c_{i}$ that satisfy the representative household's utility maximization problem; firms' profit maximization problem subject to condition that the commodity and labor markets clear, that is:

$$
\begin{gathered}
c_{i}+\sum_{j=1}^{n} x_{i j}=x_{i} \\
\sum_{i=1}^{n} l_{i}=1
\end{gathered}
$$

From the firm $i$ profit maximization problem subject to labor and input choices, $l_{i}$ and $x_{i j}$ respectively, we obtain:

$$
\begin{gathered}
l_{i}=\frac{\alpha x_{i} p_{i}}{h} \\
x_{i j}=\frac{x_{i} p_{i}(1-\alpha)\left(1+\eta \beta_{i}\right)}{p_{j}}
\end{gathered}
$$

In the next step we substitute the optimal labor and input choices into the production function. By taking logs and simplifying we arrive at the following expression:

$$
\begin{aligned}
\alpha \ln (h) & =\alpha \xi_{i}+C+\ln \left(p_{i}\right)+(1-\alpha)\left(1+\eta \beta_{i}\right) \sum_{j=1}^{n} w_{i j} \ln \left(w_{i j}\right) \\
& -(1-\alpha)\left(1+\eta \beta_{i}\right) \sum_{j=1}^{n} w_{i j} \ln \left(p_{j}\right)
\end{aligned}
$$

where $C$ is a constant independent of prices, wage and consumption defined as:

$$
C=\alpha \ln (\alpha)+(1-\alpha) \ln (1-\alpha)+(1-\alpha) \ln \left(1+\eta \beta_{i}\right)
$$


Next we multiply by the $i$ th element of the $u$ vector and we sum over all $i$.

$$
\begin{aligned}
\sum_{i=1}^{n} u_{i} \ln (h) & =\sum_{i=1}^{n} u_{i} \xi_{i}+\frac{C}{\alpha} \sum_{i=1}^{n} u_{i}+\frac{1}{\alpha} \sum_{i=1}^{n} \ln \left(p_{i}\right) u_{i} \\
& +\frac{(1-\alpha)}{\alpha} \sum_{i=1}^{n} \sum_{j=1}^{n}\left(1+\eta \beta_{i}\right) u_{i} w_{i j} \ln \left(w_{i j}\right) \\
& -\frac{(1-\alpha)}{\alpha} \sum_{i=1}^{n} \sum_{j=1}^{n}\left(1+\eta \beta_{i}\right) w_{i j} \ln \left(p_{j}\right) u_{i}
\end{aligned}
$$

Denote the vector of logarithm prices by $\ln (p)$ and the diagonal matrix of trade credit shares as $B=\operatorname{diag}\left(\beta_{1}, \ldots, \beta_{n}\right)$. Then the expression:

$$
\frac{1}{\alpha} \sum_{i=1}^{n} \ln \left(p_{i}\right) u_{i}-\frac{(1-\alpha)}{\alpha} \sum_{i=1}^{n} \sum_{j=1}^{n}\left(1+\eta \beta_{i}\right) w_{i j} \ln \left(p_{j}\right) u_{i}
$$

from the above equation in vector notation is equal to:

$$
\frac{1}{\alpha} \ln (p) u-\frac{(1-\alpha)}{\alpha}(1+\eta B) \ln (p) W^{\prime} u=\frac{1}{\alpha} \ln (p)\left[I-(1-\alpha)(1+\eta B) W^{\prime}\right] u
$$

With $u=\frac{\alpha}{n}\left[I-(1-\alpha)(1+\eta B) W^{\prime}\right]^{-1} \mathbf{1}$ the expression in (B9) simplifies to:

$$
\frac{1}{\alpha} \ln (p) u-\frac{(1-\alpha)}{\alpha}(1+\eta B) \ln (p) W^{\prime} u=\frac{1}{n} \ln (p) \mathbf{1}
$$

From constant returns to scale we have that $\sum_{i=1}^{n} u_{i}=1$. We use this property to obtain that:

$$
\begin{aligned}
& \begin{array}{l}
y=\mu+u^{\prime} \xi \\
\text { where } \quad u=\frac{\alpha}{n}\left[I-(1-\alpha)(1+\eta B) W^{\prime}\right]^{-1} \mathbf{1} \\
\text { and } \quad \mu=\frac{1}{n} \sum_{i=1}^{n} p_{i}+\frac{C}{\alpha}+\frac{1-\alpha}{\alpha} \sum_{i=1}^{n} \sum_{j=1}^{n}\left(1+\eta \beta_{i}\right) u_{i} w_{i j} \ln \left(w_{i j}\right)
\end{array}
\end{aligned}
$$

The aggregate fluctuations are equal to a sum of all firm-level shocks weighted by the importance of firms in their production and trade credit relationships. 


\section{Appendix C Taylor expansion}

We approximate vector $u$ by taking the first order Taylor approximation of $u$ around $\eta=0$ :

$$
u \approx u(0)+\frac{u^{\prime}(0)}{1 !}(\eta-0)=\frac{\alpha}{n}\left[I-(1-\alpha) W^{\prime}\right]^{-1} \mathbf{1}+\eta u^{\prime}(o)
$$

To differentiate vector $u$ we use the property that a derivative of a matrix inverse is equal to:

$$
\frac{d M^{-1}}{d \eta}=-M^{-1} \frac{d M}{d \eta} M^{-1}
$$

With the matrix $M=\left[I-(1-\alpha)(1+\eta B) W^{\prime}\right]$ we get:

$$
\begin{aligned}
\frac{d M^{-1}}{d \eta} & =-\left[I-(1-\alpha)(1+\eta B) W^{\prime}\right]^{-1} \\
& \times \frac{d\left[I-(1-\alpha)(1+\eta B) W^{\prime}\right]}{d \eta}\left[I-(1-\alpha)(1+\eta B) W^{\prime}\right]^{-1}
\end{aligned}
$$

where the derivative of matrix $\mathrm{M}$ with respect to $\eta$ is given by: $\frac{d M}{d \eta}=-(1-\alpha) B W^{\prime}$. This yields that:

$$
\begin{aligned}
u & \approx \frac{\alpha}{n}\left[I-(1-\alpha) W^{\prime}\right]^{-1} \mathbf{1}+\eta \frac{\alpha}{n}\left[I-(1-\alpha) W^{\prime}\right]^{-1}(1-\alpha) B W^{\prime}\left[I-(1-\alpha) W^{\prime}\right]^{-1} \mathbf{1} \\
& =v+\eta\left[I-(1-\alpha) W^{\prime}\right]^{-1}(1-\alpha) B W^{\prime} v
\end{aligned}
$$

\section{Appendix D Firm level relationship}

We begin from the aggregate output relationship as in equation (3) in the index notation:

$$
y=\mu+\sum_{j=1}^{n} u_{j} \xi_{j}
$$

where $u_{j}$ is the $j$ th element of vector $u$ defined as in equation (6):

$$
u \approx v+\eta\left[I-(1-\alpha) W^{\prime}\right]^{-1}(1-\alpha) B W^{\prime} v
$$


and the influence vector of Acemoglu et al. (2012) is defined as in equation (5):

$$
v=\frac{\alpha}{n}\left[I-(1-\alpha) W^{\prime}\right]^{-1} \mathbf{1}
$$

Let us define matrix $D \equiv\left[I_{n}-(1-\alpha) W^{\prime}\right]^{-1}$ such that the influence vector of Acemoglu et al. (2012) writes as $v=\frac{\alpha}{n} D \mathbf{1}$, then from (D1), (D2) and (D3) we have:

$$
y=\mu+\frac{\alpha}{n} \sum_{j=1}^{n}[D \mathbf{1}]_{j} \xi_{j}+\eta \frac{\alpha(1-\alpha)}{n} \sum_{j=1}^{n}\left[D B W^{\prime} D \mathbf{1}\right]_{j} \xi_{j},
$$

or summing also in the $i$ dimension:

$$
y=\mu+\frac{\alpha}{n} \sum_{i=1}^{n} \sum_{j=1}^{n} D_{i j} \xi_{j}+\eta \frac{\alpha(1-\alpha)}{n} \sum_{i=1}^{n} \sum_{j=1}^{n}\left[D B W^{\prime} D\right]_{i j} \xi_{j} .
$$

For $y=\sum_{i=1}^{n} y_{i}$ the expression in (D5) becomes:

$$
\sum_{i=1}^{n} y_{i}=\mu+\frac{\alpha}{n} \sum_{i=1}^{n} \sum_{j=1}^{n} D_{i j} \xi_{j}+\eta \frac{\alpha(1-\alpha)}{n} \sum_{i=1}^{n} \sum_{j=1}^{n}\left[D B W^{\prime} D\right]_{i j} \xi_{j} .
$$

which at the firm level is equivalent to:

$$
y_{i}=\mu_{i}+\frac{\alpha}{n} \sum_{j=1}^{n} D_{i j} \xi_{j}+\eta \frac{\alpha(1-\alpha)}{n} \sum_{j=1}^{n}\left[D B W^{\prime} D\right]_{i j} \xi_{j} .
$$




\section{References}

Acemoglu, Daron, Vasco M. Carvalho, Asuman Ozdaglar, and Alireza Tahbaz-Salehi, 2012, The network origins of aggregate fluctuations, Econometrica 80, 1977-2016.

Balke, Nathan S., 2000, Credit and economic activity: Credit regimes and nonlinear propagation of shocks, The Review of Economics and Statistics 82, pp. 344-349.

Barrot, Jean-NoÃńl, 2016, Trade credit and industry dynamics: Evidence from trucking firms, The Journal of Finance 71, 1975-2016.

Burkart, Mike, and Tore Ellingsen, 2004, In-kind finance: A theory of trade credit, American Economic Review 94, 569-590.

Carvalho, Vasco, and Xavier Gabaix, 2013, The great diversification and its undoing, American Economic Review 103, 1697-1727.

Cohen, Lauren, and Andrea Frazzini, 2008, Economic links and predictable returns, The Journal of Finance 63, 1977-2011.

Cuñat, Vicente, 2007, Trade credit: Suppliers as debt collectors and insurance providers, Review of Financial Studies 20, 491-527.

di Giovanni, Julian, Andrei A. Levchenko, and Isabelle Mejean, 2014, Firms, destinations, and aggregate fluctuations, Econometrica 82, 1303-1340.

Gabaix, Xavier, 2011, The granular origins of aggregate fluctuations, Econometrica 79, 733772.

Gao, Janet, 2014, Business networks, firm connectivity, and firm policies, Working Paper.

Giannetti, Mariassunta, Mike Burkart, and Tore Ellingsen, 2011, What you sell is what you lend? explaining trade credit contracts, The Review of Financial Studies 24, 1261-1298.

Jacobson, Tor, and Erik von Schedvin, 2015, Trade credit and the propagation of corporate failure: An empirical analysis, Econometrica 83, 1315-1371.

Kiyotaki, Nobuhiro, and John Moore, 1997, Credit cycles, Journal of Political Economy 105, 211-248.

— 2002, Balance-sheet contagion, The American Economic Review 92, 46-50.

Long, John B. Jr., and Charles I. Plosser, 1983, Real business cycles, Journal of Political Economy 91, 39-69.

Manski, Charles F, 1993, Identification of Endogenous Social Effects: The Reflection Problem, Review of Economic Studies 60, 531-42.

Moscarini, Giuseppe, and Fabien Postel-Vinay, 2012, The Contribution of Large and Small Employers to Job Creation in Times of High and Low Unemployment, American Economic Review 102, 2509-39. 
Petersen, Mitchell A., and Raghuram G. Rajan, 1997, Trade credit: Theories and evidence, Review of Financial Studies 10, 661-691.

Raddatz, Claudio, 2010, Credit chains and sectoral comovement: Does the use of trade credit amplify sectoral shocks?, The Review of Economics and Statistics 92, 985-1003.

Rajan, Raghuram G., and Luigi Zingales, 1998, Financial dependence and growth, The American Economic Review 88, pp. 559-586.

Shea, John S, 2002, Complementarities and Comovements, Journal of Money, Credit and Banking 34, 412-33.

Smith, Janet Kiholm, 1987, Trade credit and informational asymmetry, The Journal of Finance 42, 863-872.

Williams, Frances, 2008, World bank urged to lift trade credit finance, The Financial Times, November 11. 


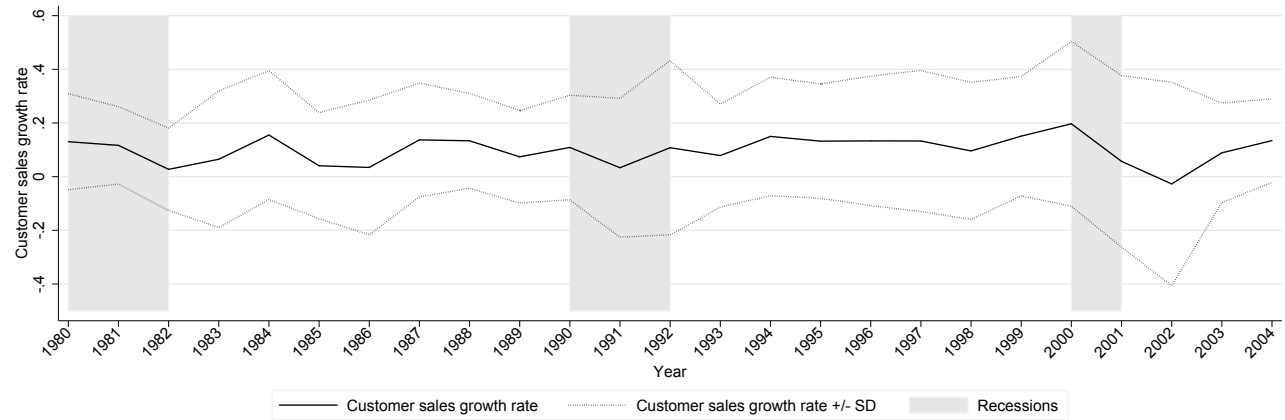

Figure 1: Customers sales growth rate. The figure shows the time series development of the average growth rate of sales among the customers. 


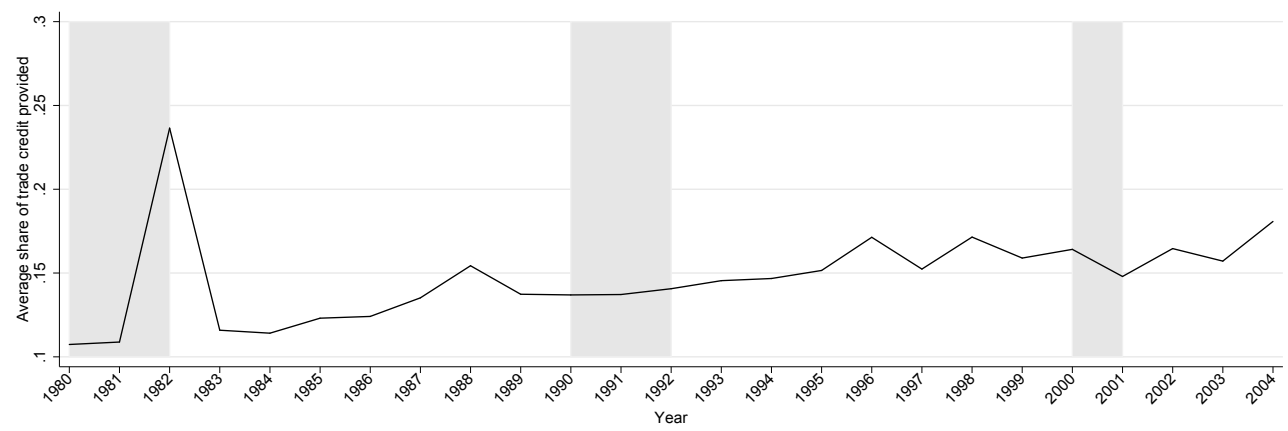

Figure 2: Share of trade credit received $\beta_{i}$. The figure shows the time series development of the average share of trade credit received $\beta_{i}$ among the customers. 


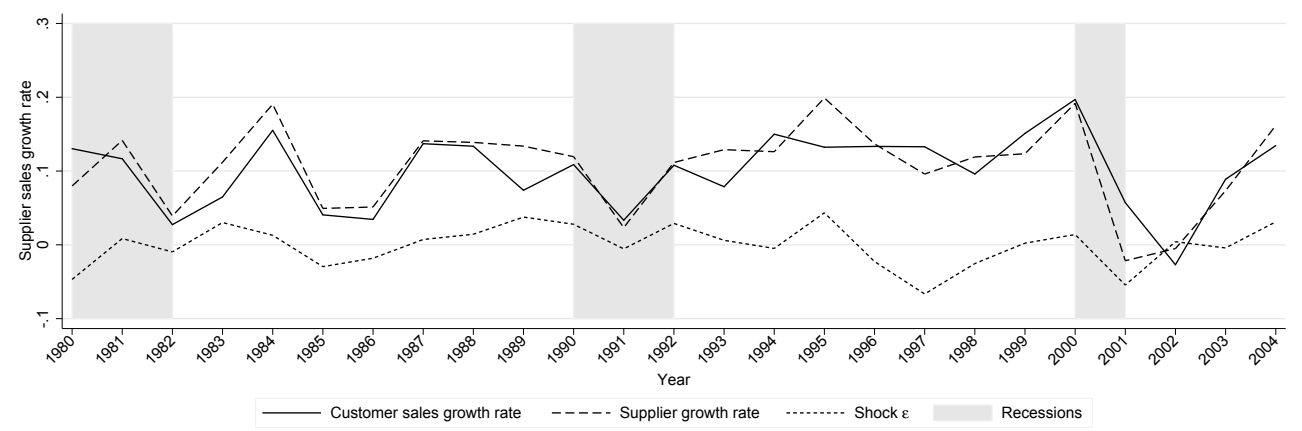

(a) Economy benchmark

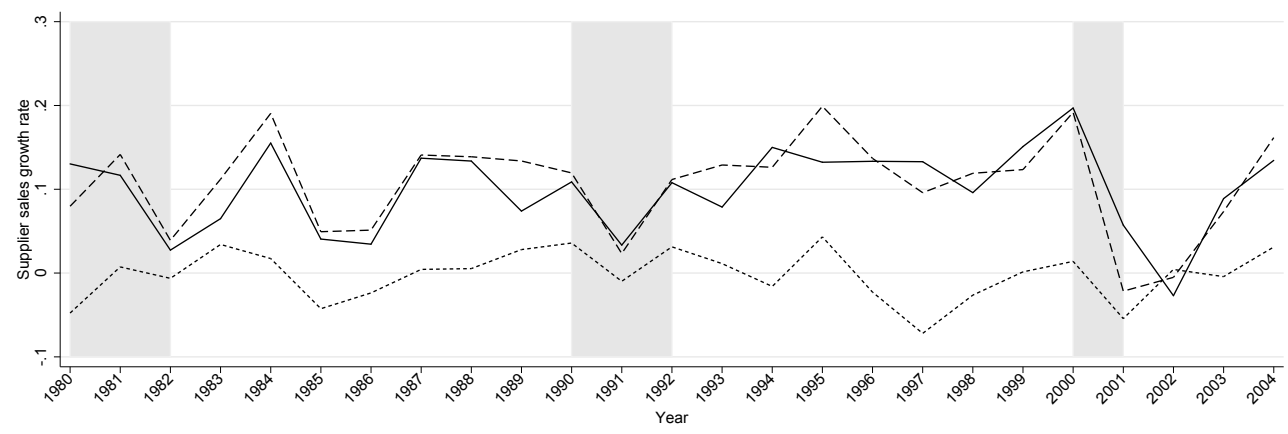

(b) Industry benchmark

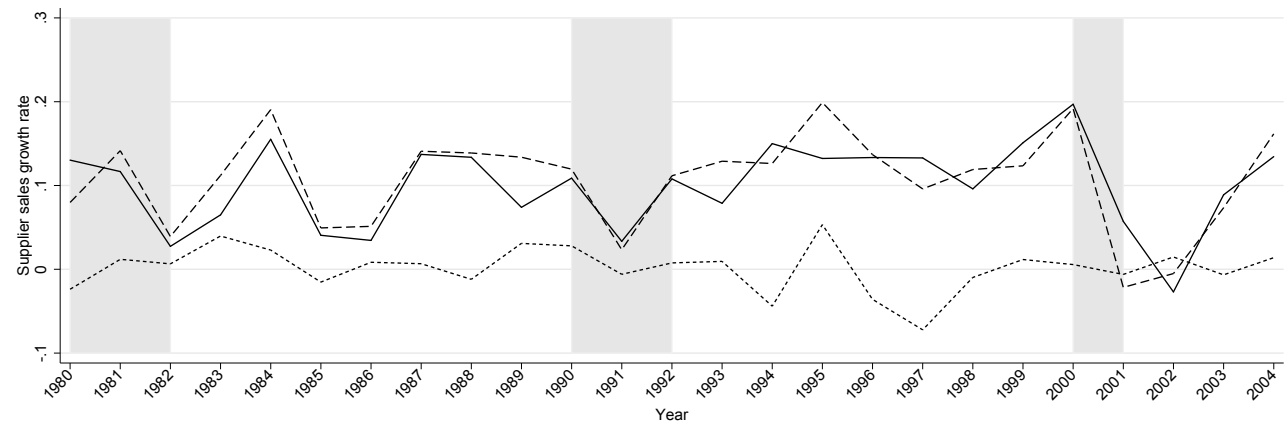

(c) State benchmark

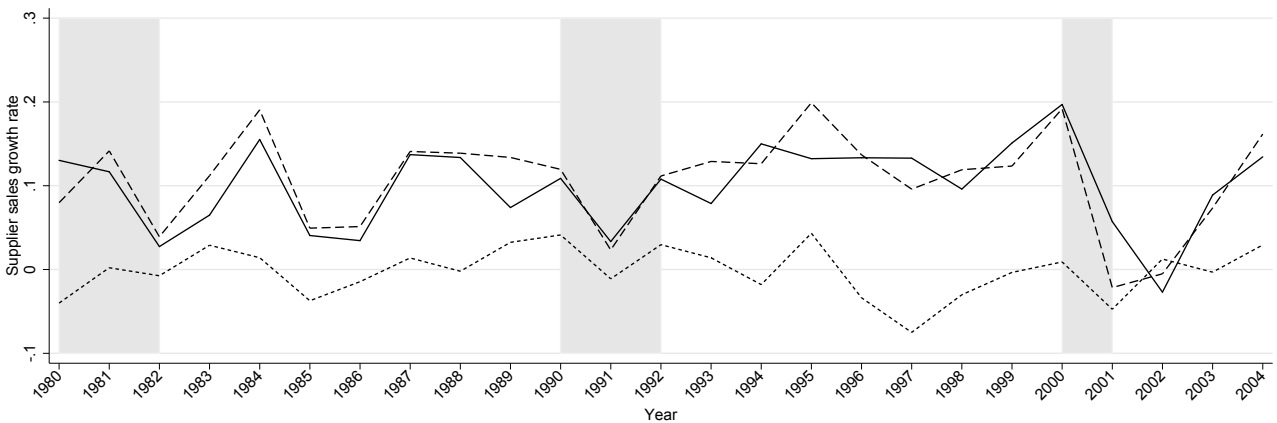

(d) County benchmark

Figure 3: Suppliers sales growth rate and the benchmark. The figure shows time series development of average growth rate of sales among suppliers. It is benchmarked against the average growth rate in the economy (Panel a), in the industry (Panel b), in the state (Panel c), in the county (Panel d). 


\section{Table I}

\section{Descriptive statistics}

The sample covers firms referred by Cohen and Frazzini (2008) as customers or suppliers with a match to Compustat balance sheet information and non-missing values of assets, cost of goods sold and non-missing values of sales in two consecutive years. Panels A, B and C summarize the sample of customers. Panels D, E and F summarize the sample of suppliers. Recession years are taken from the NBER business cycle reference dates and cover years: 1980, 1981, 1982, 1990, 1991 and 2001. The expansion years cover years: from 1983 to 1989, from 1992 to 2000 and from 2002 to 2004. The production relationship exposures are computed as $\left\{\sum_{j=1}^{n}\left(\frac{\alpha}{n} D_{i j}\right) e_{j}\right\}$ which is the first term in equation (10) and the trade credit exposures are computed as $\left\{\sum_{j=1}^{n} \beta_{i} \frac{\alpha(1-\alpha)}{n}\left[D W^{\prime} D\right]_{i j} e_{j}\right\}$ which is the second term in equation (10).

\begin{tabular}{lrrrrr}
\hline & N & \multicolumn{1}{c}{ Mean } & \multicolumn{1}{c}{ SD } & Min & Max \\
\hline Panel A: Customers descriptive statistics & - Years & 1980-2004 & & & \\
\hline Assets [\$ billions] & 4,785 & $12,693.430$ & $29,418.350$ & 1.987 & $479,921.000$ \\
EBIT [\$ billions] & 4,693 & $1,062.749$ & $2,287.461$ & $-10,537.000$ & $35,872.000$ \\
Sales [\$ billions] & 4,785 & $11,664.360$ & $23,008.660$ & 0.436 & $286,103.000$ \\
Accounts payable & 4,785 & $1,127.797$ & $2,540.814$ & 0.000 & $28,902.600$ \\
Cost of goods sold & 4,785 & $8,238.192$ & $17,858.070$ & 0.977 & $240,391.000$ \\
$w_{i j}$ & 4,785 & 0.042 & 0.176 & 0.000 & 5.127 \\
Share of trade credit received $\beta_{i}$ & 4,785 & 0.150 & 0.279 & 0.000 & 17.043 \\
Dependent variable: & & & & & \\
Sales growth rate $(g)$ & 4,785 & 0.099 & 0.249 & -2.832 & 3.765 \\
In & & & & &
\end{tabular}

\section{Independent variables:}

1) production relationship exposures (first term in equation (10)) computed relative to:

- economy benchmark

$\begin{array}{llll}4,785 & 0.002 & 0.052 & -0.78\end{array}$

$\begin{array}{llll}4,785 & 0.001 & 0.067 & -3.229\end{array}$

1.142

- industry benchmark

4,785

0.002

0.054

$-0.751$

0.958

- state benchmark

4,785

0.002

0.051

$-0.781$

1.555

2) Trade credit exposise

equation (10)) computed relative to:

- economy benchmark

4,785

0.000

0.012

4,785

0.000

0.012

$-0.266$

1.387

- industry benchmark

4,785

0.000

0.011

$-0.315$

0.710

- state benchmark

4,785

0.000

0.012

$-0.281$

0.616

- county benchmark

Panel B: Customers descriptive statistics - Expansion

$w_{i j}$

3,782

0.041

$-0.266$

0.580

Share of trade credit received $\beta_{i}$

3,782

0.151

0.182

0.000

0.695

Dependent variable:

Sales growth rate $(g)$

\section{3,782}

0.106

0.145

0.000

Independent variables:

1) production relationship exposures (first term in equation (10)) computed relative to:

- economy benchmark

- industry benchmark

$$
3,782
$$

3,782

0.002

0.054

0.000

0.073

0.056 3,782

0.002

0.052

$-2.832$

3.765

- county benchmark

0.002

ative to:

- economy benchmark

- industry benchmark

$$
3,782
$$

3,782

0.007

0.000

0.009

0.000

0.007

3,782

0.000

0.007

- state benchmark

3,782

0.000

$-3.229$

0.958

1.555

1.387

- county benchmark 
Table I cont.

\begin{tabular}{lccrrr}
\hline Panel $C$ : Customers descriptive statistics - Recession & & & & \\
\hline$w_{i j}$ & 1,003 & 0.043 & 0.154 & 0.000 & 2.612 \\
Share of trade credit received $\beta_{i}$ & 1,003 & 0.146 & 0.541 & 0.007 & 17.043 \\
$\begin{array}{l}\text { Dependent variable: } \\
\text { Sales growth rate }(g)\end{array}$ & 1,003 & 0.074 & 0.242 & -2.045 & 2.311
\end{tabular}

\section{Independent variables:}

1) production relationship exposures (first term in equation (10)) computed relative to:

\begin{tabular}{|c|c|c|c|c|c|}
\hline - economy benchmark & 1,003 & 0.001 & 0.045 & -0.397 & 0.541 \\
\hline - industry benchmark & 1,003 & 0.003 & 0.043 & -0.277 & 0.578 \\
\hline - state benchmark & 1,003 & 0.002 & 0.045 & -0.404 & 0.535 \\
\hline - county benchmark & 1,003 & 0.001 & 0.045 & -0.398 & 0.538 \\
\hline \multicolumn{6}{|c|}{ 2) Trade credit exposures (second term in equation (10)) computed relative to: } \\
\hline - economy benchmark & 1,003 & 0.001 & 0.023 & -0.021 & 0.710 \\
\hline - industry benchmark & 1,003 & 0.001 & 0.020 & -0.024 & 0.61 \\
\hline - state benchmark & 1,003 & 0.001 & 0.019 & -0.021 & 0.58 \\
\hline - county benchmark & 1,003 & 0.001 & 0.022 & -0.021 & 0.69 \\
\hline
\end{tabular}

Panel D: Suppliers descriptive statistics - Years 1980-2004

\begin{tabular}{|c|c|c|c|c|c|}
\hline Assets [\$ billions] & 9,383 & 946.294 & $4,417.068$ & 0.251 & $188,874.000$ \\
\hline EBIT [ $\$$ billions] & 9,292 & 76.940 & 492.240 & $-5,281.200$ & $12,863.000$ \\
\hline Sales [ $\$$ billions] & 9,383 & 830.639 & $3,496.323$ & 0.016 & $80,514.600$ \\
\hline Accounts payable & 9,380 & 79.916 & 376.951 & 0.000 & $8,946.788$ \\
\hline Cost of goods sold & 9,383 & 570.839 & $2,629.067$ & 0.000 & $76,956.000$ \\
\hline Sales growth rate $(g)$ & 9,383 & 0.101 & 0.452 & -2.994 & 6.367 \\
\hline \multicolumn{6}{|c|}{ Shock $(e)$ computed relative to: } \\
\hline - economy benchmark & 9,383 & -0.002 & 0.448 & -3.172 & 6.249 \\
\hline - industry benchmark & 9,383 & 0.002 & 0.427 & -3.038 & 6.136 \\
\hline - state benchmark & 9,383 & -0.001 & 0.444 & -3.246 & 6.264 \\
\hline - county benchmark & 9,383 & -0.001 & 0.445 & -3.172 & 6.250 \\
\hline \multicolumn{6}{|c|}{ Panel E: Suppliers descriptive statistics - Expansion } \\
\hline Sales growth rate $(g)$ & 7,422 & 0.116 & 0.460 & -2.994 & 6.367 \\
\hline \multicolumn{6}{|c|}{ Shock $(e)$ computed relative to: } \\
\hline - economy benchmark & 7,422 & 0.003 & 0.457 & -3.172 & 6.249 \\
\hline - industry benchmark & 7,422 & 0.003 & 0.435 & -3.038 & 6.136 \\
\hline - state benchmark & 7,422 & 0.003 & 0.453 & -3.246 & 6.264 \\
\hline - county benchmark & 7,422 & 0.005 & 0.453 & -3.172 & 6.250 \\
\hline \multicolumn{6}{|c|}{ Panel F: Suppliers descriptive statistics - Recession } \\
\hline$\overline{\text { Sales growth rate }(g)}$ & 1,961 & 0.043 & 0.418 & -2.552 & 3.875 \\
\hline \multicolumn{6}{|c|}{ Shock $(e)$ computed relative to: } \\
\hline - economy benchmark & 1,961 & -0.021 & 0.415 & -2.585 & 3.791 \\
\hline - industry benchmark & 1,961 & 0.001 & 0.391 & -2.414 & 3.715 \\
\hline - state benchmark & 1,961 & -0.017 & 0.410 & -2.568 & 3.707 \\
\hline - county benchmark & 1,961 & -0.021 & 0.412 & -2.585 & 3.787 \\
\hline
\end{tabular}


Table II

\section{Correlation between customer sales growth and supplier sales growth}

Pairwise correlation coefficients are calculated over all 12,985 observations which cover customer-supplier pairs pooled over all years with non-missing values of assets, cost of goods sold and non-missing values of sales in two consecutive years. The sales growth among customers is denoted by $g_{C u s t}$ and among supplier by $g_{S u p p}$. The economy benchmark is denoted by $\bar{g}_{E}$, the industry benchmark by $\bar{g}_{I}$, the state benchmark by $\bar{g}_{S}$, and the county benchmark by $\bar{g}_{C}$. The shock calculated relative to the economy benchmark is denoted by $e_{E}$, relative to the industry benchmark by $e_{I}$, relative to the state benchmark by $e_{S}$, and relative to the county benchmark by $e_{C}$

\begin{tabular}{|c|c|c|c|c|c|c|c|c|c|c|}
\hline & $g_{\text {Cust }}$ & $g_{\text {Supp }}$ & $\bar{g}_{E}$ & $\bar{g}_{I}$ & $\bar{g}_{S}$ & $\bar{g}_{C}$ & $e_{E}$ & $e_{I}$ & $e_{S}$ & $\frac{e_{C}}{(10)}$ \\
\hline$g_{\text {Cust }}$ & 1.000 & & & & & & & & & \\
\hline$g_{\text {Supp }}$ & 0.155 & 1.000 & & & & & & & & \\
\hline $\bar{g}_{E}$ & 0.223 & 0.131 & 1.000 & & & & & & & \\
\hline $\bar{g}_{I}$ & 0.216 & 0.332 & 0.390 & 1.000 & & & & & & \\
\hline $\bar{g}_{S}$ & 0.207 & 0.179 & 0.714 & 0.363 & 1.000 & & & & & \\
\hline $\bar{g}_{C}$ & 0.153 & 0.177 & 0.610 & 0.278 & 0.476 & 1.000 & & & & \\
\hline$e_{E}$ & 0.128 & 0.992 & 0.005 & 0.286 & 0.090 & 0.102 & 1.000 & & & \\
\hline$e_{I}$ & 0.080 & 0.930 & -0.013 & -0.038 & 0.048 & 0.079 & 0.940 & 1.000 & & \\
\hline$e_{S}$ & 0.118 & 0.982 & -0.003 & 0.268 & -0.009 & 0.090 & 0.991 & 0.936 & 1.000 & \\
\hline$e_{C}$ & 0.125 & 0.979 & 0.007 & 0.280 & 0.083 & -0.028 & 0.987 & 0.928 & 0.979 & 1.000 \\
\hline
\end{tabular}




\section{Table III}

\section{Trade credit relationship as insurance against supplier's shocks}

The table shows that in general trade credit works as insurance against suppliers' shocks by reducing disturbances to customer's sales growth. The table shows coefficient estimates of equation (10), in which the dependent variable is sales growth among customers and the supplier shock is computed relative to the economy benchmark. Column (2) shows that the effect exists even if controlling for firm, year, industry and state heterogeneity. Columns (3) and (4) show that the effect persist even if controlling for industryyear common shocks or state-year common shocks. Standard errors are given in parentheses. The figures in square brackets represent the economic effect of the production and trade credit relationships, which is the response in a customer's sales growth to a one standard deviation increase in the shock to all of its suppliers. It is given as the average over all suppliers of: $\left(\phi \frac{\alpha}{n} D_{i j} S D\left[e_{j}\right]\right)$ for the production relationship and by $\left(\eta \beta_{i} \frac{\alpha(1-\alpha)}{n}\left[D W^{\prime} D\right]_{i j} S D\left[e_{j}\right]\right)$ for the trade credit relationship. The sample runs from 1980 to 2004 . All regressions include a constant. Significance is denoted by ${ }^{*}$ at the $90 \%$ level, ${ }^{* *}$ at the $95 \%$ level and *** at $99 \%$ level.

\begin{tabular}{|c|c|c|c|c|}
\hline & \multicolumn{4}{|c|}{ Dependent variable: Customers sales growth $(g)$} \\
\hline & \multirow{2}{*}{$\begin{array}{l}\text { Baseline } \\
\text { (1) }\end{array}$} & \multirow{2}{*}{$\begin{array}{l}\text { F.E. } \\
(2)\end{array}$} & \multicolumn{2}{|c|}{ Time varying F.E. } \\
\hline & & & $(3)$ & $(4)$ \\
\hline \multirow[t]{3}{*}{$\overline{\text { Production relationship }(\phi)}$} & $1.111^{* * *}$ & $0.966^{* * *}$ & $0.976^{* * *}$ & $1.036^{* * *}$ \\
\hline & $(0.070)$ & $(0.075)$ & $(0.087)$ & $(0.071)$ \\
\hline & {$[0.005]$} & {$[0.004]$} & {$[0.004]$} & {$[0.004]$} \\
\hline \multirow{3}{*}{ Trade credit relationship $(\eta)$} & $-1.210^{* * *}$ & $-1.406^{* * *}$ & $-0.676^{*}$ & $-1.019^{* * *}$ \\
\hline & $(0.301)$ & $(0.337)$ & $(0.353)$ & $(0.303)$ \\
\hline & {$[-0.001]$} & {$[-0.001]$} & {$[-0.001]$} & {$[-0.001]$} \\
\hline Firm F.E. & No & Yes & No & No \\
\hline Year F.E. & No & Yes & No & No \\
\hline Industry F.E. & No & Yes & No & No \\
\hline State F.E. & No & Yes & No & No \\
\hline Year *Industry F.E. & No & No & Yes & No \\
\hline Year*State F.E. & No & No & No & Yes \\
\hline$N$ & 4,785 & 4,349 & 4,785 & 4,349 \\
\hline Adj.- $R^{2}$ & 0.050 & 0.352 & 0.137 & 0.127 \\
\hline
\end{tabular}




\section{Table IV \\ Trade credit and customer's importance}

The table shows coefficient estimates of equation (10), in which the dependent variable is sales growth among customers and the supplier shock is computed relative to the economy benchmark. Column (1) shows that the effect disappears if the trade credit relationship between firms is negligible $\left(\beta_{i}\right.$ among bottom $\left.10 \%\right)$. Columns (2) shows results for the model with only a production relationship. Column (3) shows results for the constrained regression in which $\phi$ is constrained to a value of one which is predicted by the theory. And column (4) focuses on a sub-sample of customers with suppliers highly dependent on their demand. We test here if the reverse causal relationship, in which the customer's growth drives positive shocks to suppliers, reveals itself by a significant coefficient on the 'Top $10 \%$ reliant suppliers' term. Standard errors in parentheses. The figures in square brackets represent the economic effect of the production and trade credit relationships, which is the response in a customer's sales growth to a one standard deviation increase in the shock to all of its suppliers. It is given as the average over all suppliers of: $\left(\phi \frac{\alpha}{n} D_{i j} S D\left[e_{j}\right]\right)$ for the production relationship and by $\left(\eta \beta_{i} \frac{\alpha(1-\alpha)}{n}\left[D W^{\prime} D\right]_{i j} S D\left[e_{j}\right]\right)$ for the trade credit relationship. The sample runs from 1980 to 2004. All regressions include a constant. Significance is denoted by * at the $90 \%$ level, ** at the $95 \%$ level and $* * *$ at $99 \%$ level.

\begin{tabular}{|c|c|c|c|c|}
\hline & \multicolumn{4}{|c|}{ Dependent variable: Customers sales growth $(g)$} \\
\hline & $\begin{array}{c}\text { Low } \beta_{i} \text { among } \\
\text { bottom } 10 \% \\
(1)\end{array}$ & $\begin{array}{c}\text { Production } \\
\text { network only } \\
(2)\end{array}$ & $\begin{array}{l}\text { Constrained } \\
\text { regression } \\
(3)\end{array}$ & $\begin{array}{l}\text { Strategic } \\
\text { customers } \\
(4)\end{array}$ \\
\hline \multirow[t]{3}{*}{$\overline{\text { Production relationship }(\phi)}$} & $1.582^{* * *}$ & $1.040^{* * *}$ & 1.000 & $1.110^{* * *}$ \\
\hline & $(0.351)$ & $(0.068)$ & constrained & $(0.070)$ \\
\hline & {$[0.007]$} & {$[0.004]$} & {$[0.004]$} & {$[0.005]$} \\
\hline \multirow{3}{*}{ Trade credit relationship $(\eta)$} & 19.501 & - & $-1.090^{* * *}$ & $-1.212^{* * *}$ \\
\hline & $(28.354)$ & & $(0.291)$ & $(0.301)$ \\
\hline & [0.018] & & {$[-0.001]$} & {$[-0.001]$} \\
\hline \multirow[t]{2}{*}{ Top $10 \%$ reliant suppliers } & & & & -0.011 \\
\hline & & & & $(0.012)$ \\
\hline F.E. & No & No & No & No \\
\hline$N$ & 489 & 4,785 & 4,785 & 4,785 \\
\hline Adj.- $R^{2}(M S E$ in column $(3))$ & 0.043 & 0.047 & 0.243 & 0.051 \\
\hline
\end{tabular}




\section{Table V \\ Trade credit and financial constraints}

The table shows coefficient estimates of equation (10), in which the dependent variable is sales growth among customers and the supplier shock is computed relative to the economy benchmark. Column (1) shows that the trade credit relationship reduces disturbances to customer's sales growth during good times but not during recession. Recession years are taken from the NBER business cycle reference dates and cover years: 1980, 1981, 1982, 1990, 1991 and 2001. The expansion years cover years: from 1983 to 1989 , from 1992 to 2000 and from 2002 to 2004. Column (2) shows that for cash poor customers, a trade credit relationship amplifies disturbances to sales growth. This stems from the positive sign on the interaction term between the trade credit relationship and a dummy for cash poor customers. The cash poor customers are defined as $5 \%$ of the customers which in the previous year had the lowest liquid assets relative to their sales. Column (3) illustrates that for financially constrained firms the existence of a trade credit relationship translates into higher disturbances in sales growth from suppliers shocks. Financial constraint is computed according to Rajan and Zingales (1998). Column (4) shows that trade credit relationship translates into higher disturbances in sales growth either during recession or for financially constrained firms. The sample runs from 1980 to 2004. Standard errors in parentheses. The figures in square brackets represent the economic effect of the production and trade credit relationships, which is the response in a customer's sales growth to a one standard deviation increase in the shock to all of its suppliers. It is given as the average over all suppliers of: $\left(\phi \frac{\alpha}{n} D_{i j} S D\left[e_{j}\right]\right)$ for the production relationship and by $\left(\eta \beta_{i} \frac{\alpha(1-\alpha)}{n}\left[D W^{\prime} D\right]_{i j} S D\left[e_{j}\right]\right)$ for the trade credit relationship. The sample runs from 1980 to 2004. All regressions include a constant. Significance is denoted by * at the $90 \%$ level, ${ }^{* *}$ at the $95 \%$ level and *** at $99 \%$ level.

\begin{tabular}{|c|c|c|c|c|}
\hline & \multicolumn{4}{|c|}{ Dependent variable: Customers sales growth $(g)$} \\
\hline & \multirow{2}{*}{$\begin{array}{l}\text { Recession } \\
\text { (1) }\end{array}$} & \multirow{2}{*}{$\begin{array}{c}\text { Cash reserves } \\
(2)\end{array}$} & \multicolumn{2}{|c|}{$\begin{array}{r}\text { Fin. dependence Fin. dependence } \\
\text { in recession }\end{array}$} \\
\hline & & & (3) & (4) \\
\hline \multirow[t]{3}{*}{ Production relationship $(\phi)$} & $1.310^{* * *}$ & $1.014^{* * *}$ & $1.237^{* * *}$ & $1.359^{* * *}$ \\
\hline & $(0.075)$ & $(0.093)$ & $(0.074)$ & $(0.077)$ \\
\hline & {$[0.006]$} & {$[0.004]$} & {$[0.005]$} & {$[0.006]$} \\
\hline \multirow[t]{3}{*}{ Trade credit relationship $(\eta)$} & $-5.233^{* * *}$ & $-4.761^{* * *}$ & $-10.017^{* * *}$ & $-11.616^{* * *}$ \\
\hline & $(0.629)$ & $(0.860)$ & $(1.287)$ & $(1.373)$ \\
\hline & {$[-0.005]$} & {$[-0.004]$} & {$[-0.009]$} & {$[-0.011]$} \\
\hline \multirow[t]{2}{*}{ Trade credit relationship*Recession } & $\begin{array}{l}5.186^{* * *} \\
(0.709)\end{array}$ & & & $\begin{array}{l}7.418^{* *} \\
(3.742)\end{array}$ \\
\hline & {$[0.005]$} & & & {$[0.007]$} \\
\hline Recession & $-0.031^{* * *}$ & & & $-0.031^{* * *}$ \\
\hline \multirow{3}{*}{$\begin{array}{l}\text { Trade credit relationship*Top } 10 \% \\
\text { dependent on ext. fin. }\end{array}$} & & & $9.203^{* * *}$ & $7.710^{* * *}$ \\
\hline & & & $(1.303)$ & $(1.448)$ \\
\hline & & & {$[0.009]^{2}$} & {$[0.007]$} \\
\hline Top $10 \%$ dependent on ext. fin. & & & $\begin{array}{l}-0.071^{* * *} \\
(0.012)\end{array}$ & $\begin{array}{l}-0.069^{* * *} \\
(0.012)\end{array}$ \\
\hline Trade credit relationship*Recession & & & & -3.528 \\
\hline *Top 10\% dependent on ext. fin. & & & & $\begin{array}{r}(3.798) \\
{[-0.003]}\end{array}$ \\
\hline \multirow{3}{*}{$\begin{array}{l}\text { Trade credit relationship*Bottom } 5 \% \\
\text { cash poor firms }\end{array}$} & & $72.219 * * *$ & & \\
\hline & & $(20.554)$ & & \\
\hline & & [0.068] & & \\
\hline \multirow[t]{2}{*}{ Bottom $5 \%$ cash poor firms } & & $0.035^{* *}$ & & \\
\hline & & $(0.016)$ & & \\
\hline F.E. & No & No & No & No \\
\hline$N$ & 4,785 & 3,245 & 4,728 & 4,728 \\
\hline Adj. $-R^{2}$ & 0.063 & 0.039 & 0.065 & 0.073 \\
\hline
\end{tabular}




\section{Table VI \\ Trade credit and financial constraints - robustness}

The table shows coefficient estimates of equation (10), in which the dependent variable is sales growth among customers and the supplier shock is computed relative to the economy benchmark. Column (1) and (2) control for customer level common shocks and show that during recession firms which high use of trade credit suffer higher disturbances to their sales growth than those with only small use of trade credit. Also, financially constrained firms with high use of trade credit will suffer higher disturbances than financially constrained firms with little trade credit. Recession years are taken from the NBER business cycle reference dates and cover years: 1980, 1981, 1982, 1990, 1991 and 2001. The expansion years cover years: from 1983 to 1989 , from 1992 to 2000 and from 2002 to 2004. Column (3) and (4) show no significant relationship for customers with highly dependent supplier. The sample runs from 1980 to 2004. Standard errors in parentheses. The figures in square brackets represent the economic effect of the production and trade credit relationships, which is the response in a customer's sales growth to a one standard deviation increase in the shock to all of its suppliers. It is given as the average over all suppliers of: $\left(\phi \frac{\alpha}{n} D_{i j} S D\left[e_{j}\right]\right)$ for the production relationship and by $\left(\eta \beta_{i} \frac{\alpha(1-\alpha)}{n}\left[D W^{\prime} D\right]_{i j} S D\left[e_{j}\right]\right)$ for the trade credit relationship. The sample runs from 1980 to 2004. All regressions include a constant. Significance is denoted by * at the $90 \%$ level, ** at the $95 \%$ level and $* * *$ at $99 \%$ level.

\begin{tabular}{|c|c|c|c|c|}
\hline & \multicolumn{4}{|c|}{ Dependent variable: Customers sales growth $(g)$} \\
\hline & \multicolumn{2}{|c|}{ Time varying F.E. } & \multicolumn{2}{|c|}{ Strategic customers } \\
\hline & $\begin{array}{l}\text { Recession } \\
\text { (1) }\end{array}$ & $\begin{array}{c}\text { Fin. dependence } \\
(2)\end{array}$ & $\begin{array}{c}\text { Recession } \\
\text { (3) }\end{array}$ & $\begin{array}{l}\text { Fin. dependence } \\
\text { (4) }\end{array}$ \\
\hline Production relationship $(\phi)$ & $1.221^{* * *}$ & $1.150^{* * *}$ & $1.309^{* * *}$ & $1.236^{* * *}$ \\
\hline & $(0.076)$ & $(0.075)$ & $(0.075)$ & $(0.074)$ \\
\hline & {$[0.005]$} & {$[0.005]$} & {$[0.006]$} & {$[0.005]$} \\
\hline Trade credit relationship $(\eta)$ & $\begin{array}{l}-4.936^{* * *} \\
(0.658)\end{array}$ & $\begin{array}{l}-10.599^{* * *} \\
(1.431)\end{array}$ & $\begin{array}{l}-5.235^{* * *} \\
(0.629)\end{array}$ & $\begin{array}{l}-10.023^{* * *} \\
(1.287)\end{array}$ \\
\hline & {$[-0.005]$} & {$[-0.010]$} & {$[-0.005]$} & {$[-0.009]$} \\
\hline Trade credit relationship*Recession & $\begin{array}{l}4.917^{* * *} \\
(0.735)\end{array}$ & & $\begin{array}{l}5.187^{* * *} \\
(0.709)\end{array}$ & \\
\hline & [0.005] & & {$[0.005]$} & \\
\hline Recession & $\begin{array}{r}0.176 \\
(0.462)\end{array}$ & & $\begin{array}{l}-0.031^{* * *} \\
(0.009)\end{array}$ & \\
\hline $\begin{array}{l}\text { Trade credit relationship*Top } 10 \% \\
\text { dependent on ext. fin. }\end{array}$ & & $\begin{array}{l}9.937^{* * *} \\
(1.445) \\
{[0.009]}\end{array}$ & & $\begin{array}{l}9.208^{* * *} \\
(1.303) \\
{[0.009]}\end{array}$ \\
\hline Top $10 \%$ dependent on ext. fin. & & $\begin{array}{r}-0.070 \\
(0.013)\end{array}$ & & $\begin{array}{l}-0.071^{* * *} \\
(0.012)\end{array}$ \\
\hline Top 10\% reliant suppliers & & & $\begin{array}{r}-0.011 \\
(0.012)\end{array}$ & $\begin{array}{r}-0.012 \\
(0.012)\end{array}$ \\
\hline Year*State F.E. & Yes & Yes & No & No \\
\hline$N$ & 4,349 & 4,308 & 4,785 & 4,728 \\
\hline Adj.- $R^{2}$ & 0.138 & 0.148 & 0.063 & 0.065 \\
\hline
\end{tabular}




\section{Table VII \\ Industry benchmark}

Panel A shows that a trade credit relationship reduces disturbances to sales growth. It shows coefficient estimates of equation (10), in which the dependent variable is sales growth among customers and the supplier shock is computed relative to the industry benchmark. Panel B shows that the insurance effect is irrespective of the customer's importance, which suggests no reverse causality. Panel $\mathrm{C}$ shows that the trade credit insurance effect is absent during recession or for cash poor firms or for financially constrained firms. Panel D shows that the trade credit insurance effect is absent in those cases even if controlling for state-year common shocks. Standard errors in parentheses. The figures in square brackets represent the economic effect of the production and trade credit relationships, which is the response in a customer's sales growth to a one standard deviation increase in the shock to all of its suppliers. It is given as the average over all suppliers of: $\left(\phi \frac{\alpha}{n} D_{i j} S D\left[e_{j}\right]\right)$ for the production relationship and by $\left(\eta \beta_{i} \frac{\alpha(1-\alpha)}{n}\left[D W^{\prime} D\right]_{i j} S D\left[e_{j}\right]\right)$ for the trade credit relationship. The sample runs from 1980 to 2004. All regressions include a constant. Significance is denoted by * at the $90 \%$ level, ** at the $95 \%$ level and *** at $99 \%$ level.

\begin{tabular}{|c|c|c|c|c|}
\hline & \multicolumn{4}{|c|}{ Dependent variable: Customers sales growth $(g)$} \\
\hline \multicolumn{5}{|c|}{ Panel A: Trade credit as insurance against supplier's shocks } \\
\hline & \multirow{2}{*}{$\begin{array}{c}\text { Baseline } \\
(1)\end{array}$} & \multirow{2}{*}{$\begin{array}{l}\text { F.E. } \\
(2)\end{array}$} & \multicolumn{2}{|c|}{ Time varying F.E. } \\
\hline & & & $(3)$ & $(4)$ \\
\hline \multirow[t]{3}{*}{ Production relationship $(\phi)$} & $0.626^{* * *}$ & $0.539 * * *$ & $0.631^{* * *}$ & $0.573^{* * *}$ \\
\hline & $(0.058)$ & $(0.063)$ & $(0.069)$ & $(0.059)$ \\
\hline & [0.003] & {$[0.002]$} & {$[0.003]$} & {$[0.002]$} \\
\hline \multirow[t]{3}{*}{ Trade credit relationship $(\eta)$} & $-1.531^{* * *}$ & $-1.552^{* * *}$ & $-1.283^{* * *}$ & $-1.420^{* * *}$ \\
\hline & $(0.332)$ & $(0.374)$ & $(0.397)$ & $(0.336)$ \\
\hline & {$[-0.001]$} & {$[-0.001]$} & {$[-0.001]$} & {$[-0.001]$} \\
\hline Firm F.E. & No & Yes & No & No \\
\hline Year F.E. & No & Yes & No & No \\
\hline Industry F.E. & No & Yes & No & No \\
\hline State F.E. & No & Yes & No & No \\
\hline Year *Industry F.E. & No & No & Yes & No \\
\hline Year*State F.E. & No & No & No & Yes \\
\hline$N$ & 4,785 & 4,349 & 4,785 & 4,349 \\
\hline Adj.- $R^{2}$ & 0.024 & 0.335 & 0.123 & 0.099 \\
\hline \multicolumn{5}{|l|}{ Panel B: Customer's importance } \\
\hline & $\begin{array}{c}\text { Low } \beta_{i} \text { among } \\
\text { bottom } 10 \%\end{array}$ & $\begin{array}{l}\text { Production } \\
\text { network only }\end{array}$ & $\begin{array}{l}\text { Constrained } \\
\text { regression }\end{array}$ & $\begin{array}{l}\text { Strategic } \\
\text { customers }\end{array}$ \\
\hline \multirow[t]{3}{*}{ Production relationship $(\phi)$} & $1.354^{* * *}$ & $0.518^{* * *}$ & 1.000 & $0.625^{* * *}$ \\
\hline & $(0.365)$ & $(0.053)$ & constrained & $(0.058)$ \\
\hline & {$[0.006]$} & [0.002] & {$[0.004]$} & {$[0.003]$} \\
\hline \multirow[t]{3}{*}{ Trade credit relationship $(\eta)$} & -30.921 & & $-2.400 * * *$ & $-1.531^{* * *}$ \\
\hline & $(23.411)$ & & $(0.305)$ & $(0.332)$ \\
\hline & {$[-0.028]$} & & {$[-0.002]$} & {$[-0.001]$} \\
\hline \multirow[t]{2}{*}{ Top 10\% reliant suppliers } & & & & -0.013 \\
\hline & & & & $(0.012)$ \\
\hline F.E. & No & No & No & No \\
\hline$N$ & 489 & 4,785 & 4,785 & 4,785 \\
\hline Adj.- $R^{2}(M S E$ in column (3)) & 0.024 & 0.019 & 0.248 & 0.024 \\
\hline
\end{tabular}


Table VII cont.

\begin{tabular}{|c|c|c|c|c|}
\hline \multirow{4}{*}{ Panel C: Financial constraints } & \multicolumn{4}{|c|}{ Dependent variable: Customers sales growth $(g)$} \\
\hline & & & & \\
\hline & \multirow{2}{*}{$\begin{array}{c}\text { Recession } \\
\text { (1) }\end{array}$} & \multirow{2}{*}{$\begin{array}{c}\text { Cash reserves } \\
\text { (2) }\end{array}$} & \multicolumn{2}{|c|}{$\begin{array}{c}\text { Fin. dependence Fin. dependence } \\
\text { in recession }\end{array}$} \\
\hline & & & (3) & (4) \\
\hline \multirow[t]{3}{*}{$\overline{\text { Production relationship }(\phi)}$} & $0.861^{* * *}$ & $0.616^{* * *}$ & $0.636^{* * *}$ & $0.840^{* * *}$ \\
\hline & $(0.066)$ & $(0.082)$ & $(0.059)$ & $(0.067)$ \\
\hline & {$[0.004]$} & {$[0.003]$} & {$[0.003]$} & {$[0.003]$} \\
\hline \multirow[t]{2}{*}{ Trade credit relationship $(\eta)$} & $\begin{array}{l}-4.990^{* * *} \\
(0.584)\end{array}$ & $\begin{array}{l}-4.820^{* * *} \\
(0.856)\end{array}$ & $\begin{array}{l}-7.031^{* * *} \\
(1.520)\end{array}$ & $\begin{array}{l}-9.133^{* * *} \\
(1.562)\end{array}$ \\
\hline & {$[-0.004]$} & {$[-0.004]$} & {$[-0.006]$} & {$[-0.008]$} \\
\hline \multirow[t]{2}{*}{ Trade credit relationship*Recession } & $4.367^{* * *}$ & & & $7.404^{* *}$ \\
\hline & $\begin{array}{l}(0.603) \\
{[0.004]}\end{array}$ & & & $\begin{array}{l}(3.040) \\
{[0.007]}\end{array}$ \\
\hline \multirow[t]{2}{*}{ Recession } & $-0.034^{* * *}$ & & & $-0.034^{* * *}$ \\
\hline & $(0.009)$ & & & $(0.009)$ \\
\hline \multirow{2}{*}{$\begin{array}{l}\text { Trade credit relationship*Top } 10 \% \\
\text { dependent on ext. fin. }\end{array}$} & & & $\begin{array}{l}5.724^{* * *} \\
(1.524)\end{array}$ & $\begin{array}{l}4.724^{* * *} \\
(1.575)\end{array}$ \\
\hline & & & {$[0.005]$} & {$[0.004]$} \\
\hline Top $10 \%$ dependent on ext. fin. & & & $\begin{array}{l}-0.076^{* * *} \\
(0.012)\end{array}$ & $\begin{array}{l}-0.074^{* * *} \\
(0.012)\end{array}$ \\
\hline \multirow{2}{*}{$\begin{array}{l}\text { Trade credit relationship*Recession } \\
* \text { Top } 10 \% \text { dependent on ext. fin. }\end{array}$} & & & & -4.106 \\
\hline & & & & $\begin{array}{l}(3.566) \\
{[-0.004]}\end{array}$ \\
\hline \multirow{3}{*}{$\begin{array}{l}\text { Trade credit relationship*Bottom } 5 \% \\
\text { cash poor firms }\end{array}$} & & 14.932 & & \\
\hline & & $(26.059)$ & & \\
\hline & & {$[0.013]$} & & \\
\hline \multirow[t]{2}{*}{ Bottom $5 \%$ cash poor firms } & & $0.028^{*}$ & & \\
\hline & & $(0.016)$ & & \\
\hline F.E. & No & No & No & No \\
\hline$N$ & 4,785 & 3,245 & 4,728 & 4,728 \\
\hline Adj.- $R^{2}$ & 0.037 & 0.017 & 0.033 & 0.044 \\
\hline \multicolumn{5}{|c|}{$\overline{\text { Panel D: Financial constraints - robustness }}$} \\
\hline & \multicolumn{2}{|c|}{ Time varying F.E. } & \multicolumn{2}{|c|}{ Strategic customers } \\
\hline & Recession & Fin. dependence & Recession & Fin. dependence \\
\hline \multirow[t]{3}{*}{ Production relationship $(\phi)$} & $0.810^{* * *}$ & $0.584^{* * *}$ & $0.860^{* * *}$ & $0.635^{* * *}$ \\
\hline & $(0.067)$ & $(0.060)$ & $(0.066)$ & $(0.059)$ \\
\hline & {$[0.003]$} & {$[0.002]$} & {$[0.004]$} & [0.003] \\
\hline \multirow[t]{3}{*}{ Trade credit relationship $(\eta)$} & $-5.015^{* * *}$ & $-8.422^{* * *}$ & $-4.989^{* * *}$ & $-7.037 * * *$ \\
\hline & $(0.607)$ & $(1.709)$ & $(0.584)$ & $(1.520)$ \\
\hline & {$[-0.004]$} & {$[-0.007]$} & {$[-0.004]$} & {$[-0.006]$} \\
\hline \multirow[t]{3}{*}{ Trade credit relationship*Recession } & $4.397^{* * *}$ & & $4.365^{* * *}$ & \\
\hline & $(0.621)$ & & $(0.603)$ & \\
\hline & {$[0.004]$} & & {$[0.004]$} & \\
\hline \multirow[t]{2}{*}{ Recession } & -0.167 & & $-0.034^{* * *}$ & \\
\hline & $(0.741)$ & & $(0.009)$ & \\
\hline \multirow{3}{*}{$\begin{array}{l}\text { Trade credit relationship*Top } 10 \% \\
\text { dependent on ext. fin. }\end{array}$} & & $7.228^{* * *}$ & & $5.729^{* * *}$ \\
\hline & & $(1.712)$ & & $(1.524)$ \\
\hline & & {$[0.006]$} & & {$[0.005]$} \\
\hline Top $10 \%$ dependent on ext. fin. & & -0.075 & & $-0.076^{* * *}$ \\
\hline & & $(0.013)$ & & $(0.012)$ \\
\hline Top 10\% reliant suppliers & & & -0.012 & -0.014 \\
\hline & & & $(0.012)$ & $(0.012)$ \\
\hline Year*State F.E. & Yes & Yes & No & No \\
\hline$N$ & 4,349 & 4,308 & 4,785 & 4,728 \\
\hline Adj.- $R^{2}$ & 0.112 & 0.115 & 0.037 & 0.033 \\
\hline
\end{tabular}




\section{Table VIII \\ State benchmark}

Panel A shows that a trade credit relationship reduces disturbances to sales growth. It shows coefficient estimates of equation (10), in which the dependent variable is sales growth among customers and the supplier shock is computed relative to the state benchmark. Panel B shows that the insurance effect is irrespective of the customer's importance, which suggests no reverse causality. Panel $\mathrm{C}$ shows that the trade credit insurance effect is absent during recession or for cash poor firms or for financially constrained firms. Panel D shows that the trade credit insurance effect is absent in those cases even if controlling for state-year common shocks. Standard errors in parentheses. The figures in square brackets represent the economic effect of the production and trade credit relationships, which is the response in a customer's sales growth to a one standard deviation increase in the shock to all of its suppliers. It is given as the average over all suppliers of: $\left(\phi \frac{\alpha}{n} D_{i j} S D\left[e_{j}\right]\right)$ for the production relationship and by $\left(\eta \beta_{i} \frac{\alpha(1-\alpha)}{n}\left[D W^{\prime} D\right]_{i j} S D\left[e_{j}\right]\right)$ for the trade credit relationship. The sample runs from 1980 to 2004. All regressions include a constant. Significance is denoted by ${ }^{*}$ at the $90 \%$ level, $* *$ at the $95 \%$ level and $* * *$ at $99 \%$ level.

\begin{tabular}{|c|c|c|c|c|}
\hline & \multicolumn{4}{|c|}{ Dependent variable: Customers sales growth $(g)$} \\
\hline \multicolumn{5}{|c|}{ Panel A: Trade credit as insurance against supplier's shocks } \\
\hline & \multirow{2}{*}{$\begin{array}{c}\text { Baseline } \\
\text { (1) }\end{array}$} & \multirow{2}{*}{$\begin{array}{l}\text { F.E. } \\
(2)\end{array}$} & \multicolumn{2}{|c|}{ Time varying F.E. } \\
\hline & & & $(3)$ & $(4)$ \\
\hline \multirow[t]{3}{*}{ Production relationship $(\phi)$} & $1.049^{* * *}$ & $0.929^{* * *}$ & $0.943^{* * *}$ & $1.019^{* * *}$ \\
\hline & $(0.069)$ & $(0.074)$ & $(0.085)$ & $(0.071)$ \\
\hline & {$[0.004]$} & {$[0.004]$} & {$[0.004]$} & {$[0.004]$} \\
\hline \multirow[t]{3}{*}{ Trade credit relationship $(\eta)$} & $-1.623^{* * *}$ & $-1.729 * * *$ & $-0.969 * *$ & $-1.460 * * *$ \\
\hline & $(0.345)$ & $(0.383)$ & $(0.419)$ & $(0.348)$ \\
\hline & {$[-0.002]$} & {$[-0.002]$} & {$[-0.001]$} & {$[-0.001]$} \\
\hline Firm F.E. & No & Yes & No & No \\
\hline Year F.E. & No & Yes & No & No \\
\hline Industry F.E. & No & Yes & No & No \\
\hline State F.E. & No & Yes & No & No \\
\hline Year *Industry F.E. & No & No & Yes & No \\
\hline Year*State F.E. & No & No & No & Yes \\
\hline$N$ & 4,785 & 4,349 & 4,785 & 4,349 \\
\hline $\operatorname{Adj} .-R^{2}$ & 0.046 & 0.351 & 0.135 & 0.126 \\
\hline \multicolumn{5}{|l|}{ Panel B: Customer's importance } \\
\hline & $\begin{array}{c}\text { Low } \beta_{i} \text { among } \\
\text { bottom } 10 \%\end{array}$ & $\begin{array}{c}\text { Production } \\
\text { networks only }\end{array}$ & $\begin{array}{l}\text { Constrained } \\
\text { regression }\end{array}$ & $\begin{array}{l}\text { Strategic } \\
\text { customers }\end{array}$ \\
\hline \multirow[t]{3}{*}{$\overline{\text { Production relationship }(\phi)}$} & $1.538^{* * *}$ & $0.951^{* * *}$ & 1.000 & $1.048^{* * *}$ \\
\hline & $(0.335)$ & $(0.066)$ & constrained & $(0.069)$ \\
\hline & {$[0.007]$} & {$[0.004]$} & {$[0.004]$} & {$[0.004]$} \\
\hline \multirow[t]{3}{*}{ Trade credit relationship $(\eta)$} & 44.904 & & $-1.549 * * *$ & $-1.625 * * *$ \\
\hline & $(29.239)$ & & $(0.329)$ & $(0.345)$ \\
\hline & {$[0.042]$} & & {$[-0.001]$} & {$[-0.002]$} \\
\hline \multirow[t]{2}{*}{ Top $10 \%$ reliant suppliers } & & & & -0.012 \\
\hline & & & & $(0.012)$ \\
\hline F.E. & No & No & No & No \\
\hline$N$ & 489 & 4,785 & 4,785 & 4,785 \\
\hline Adj.- $R^{2}(M S E$ in column (3)) & 0.050 & 0.042 & 0.244 & 0.046 \\
\hline
\end{tabular}


Table VIII cont.

\begin{tabular}{|c|c|c|c|c|}
\hline \multirow{3}{*}{ Panel C: Financial constraints } & \multicolumn{4}{|c|}{ Dependent variable: Customers sales growth $(g)$} \\
\hline & \multirow{3}{*}{$\begin{array}{c}\text { Recession } \\
\text { (1) }\end{array}$} & \multirow{3}{*}{$\begin{array}{c}\text { Cash reserves } \\
(2)\end{array}$} & & \\
\hline & & & \multirow{2}{*}{$\begin{array}{c}\text { Fin. dependence } \\
(3)\end{array}$} & \multirow{2}{*}{$\begin{array}{l}\text { Fin. dependence } \\
\text { in recession } \\
(4)\end{array}$} \\
\hline & & & & \\
\hline \multirow[t]{3}{*}{ Production relationship $(\phi)$} & $1.240^{* * *}$ & $0.947^{* * *}$ & $1.134^{* * *}$ & $1.270^{* * *}$ \\
\hline & $(0.074)$ & $(0.093)$ & $(0.072)$ & $(0.076)$ \\
\hline & {$[0.005]$} & {$[0.004]$} & {$[0.005]$} & {$[0.005]$} \\
\hline \multirow{3}{*}{ Trade credit relationship $(\eta)$} & $-5.129 * * *$ & $-4.976 * * *$ & $-9.063^{* * *}$ & $-10.753^{* * *}$ \\
\hline & $(0.606)$ & $(0.865)$ & $(1.276)$ & $(1.371)$ \\
\hline & {$[-0.005]$} & {$[-0.005]$} & {$[-0.008]$} & {$[-0.010]$} \\
\hline \multirow[t]{3}{*}{ Trade credit relationship*Recession } & $4.221^{* * *}$ & & & $7.447^{* *}$ \\
\hline & $(0.597)$ & & & $(3.721)$ \\
\hline & {$[0.004]$} & & & {$[0.007]$} \\
\hline \multirow[t]{2}{*}{ Recession } & $-0.032^{* * *}$ & & & $-0.031^{* * *}$ \\
\hline & $(0.009)$ & & & $(0.009)$ \\
\hline \multirow{3}{*}{$\begin{array}{l}\text { Trade credit relationship*Top } 10 \% \\
\text { dependent on ext. fin. }\end{array}$} & & & $7.903^{* * *}$ & $6.710^{* * *}$ \\
\hline & & & $(1.296)$ & $(1.429)$ \\
\hline & & & {$[0.007]$} & {$[0.006]$} \\
\hline \multirow{2}{*}{ Top $10 \%$ dependent on ext. fin. } & & & $-0.072^{* * *}$ & $-0.070^{* * *}$ \\
\hline & & & $(0.012)$ & $(0.012)$ \\
\hline Trade credit relationship*Recession & & & & -5.007 \\
\hline \multirow[t]{2}{*}{ *Top $10 \%$ dependent on ext. fin. } & & & & $(4.592)$ \\
\hline & & & & {$[-0.005]$} \\
\hline Trade credit relationship*Bottom $5 \%$ & & $68.379^{* * *}$ & & \\
\hline \multirow[t]{2}{*}{ cash poor firms } & & $(19.663)$ & & \\
\hline & & [0.063] & & \\
\hline \multirow{2}{*}{ Bottom $5 \%$ cash poor firms } & & $0.033^{* *}$ & & \\
\hline & & $(0.016)$ & & \\
\hline F.E. & No & No & No & No \\
\hline$N$ & 4,785 & 3,245 & 4,728 & 4,728 \\
\hline Adj.- $R^{2}$ & 0.058 & 0.034 & 0.059 & 0.067 \\
\hline \multicolumn{5}{|c|}{ Panel D: Financial constraints - robustness } \\
\hline & \multicolumn{2}{|c|}{ Time varying F.E. } & \multicolumn{2}{|c|}{ Strategic customers } \\
\hline & Recession & Fin. dependence & Recession & Fin. dependence \\
\hline \multirow[t]{3}{*}{ Production relationship $(\phi)$} & $1.208^{* * *}$ & $1.102^{* * *}$ & $1.239^{* * *}$ & $1.133^{* * *}$ \\
\hline & $(0.076)$ & $(0.073)$ & $(0.074)$ & $(0.072)$ \\
\hline & {$[0.005]$} & {$[0.005]$} & {$[0.005]$} & {$[0.005]$} \\
\hline Trade credit relationship $(\eta)$ & $-5.055^{* * *}$ & $-9.962^{* * *}$ & $-5.132^{* * *}$ & $-9.073^{* * *}$ \\
\hline & $(0.633)$ & $(1.415)$ & $(0.606)$ & $(1.276)$ \\
\hline & {$[-0.005]$} & {$[-0.009]$} & {$[-0.005]$} & {$[-0.008]$} \\
\hline Trade credit relationship*Recession & $4.168^{* * *}$ & & $4.222^{* * *}$ & \\
\hline & $(0.615)$ & & $(0.597)$ & \\
\hline & {$[0.004]$} & & {$[0.004]$} & \\
\hline Recession & 0.176 & & $-0.032^{* * *}$ & \\
\hline & $(0.462)$ & & $(0.009)$ & \\
\hline Trade credit relationship*Top $10 \%$ & & $8.939^{* * *}$ & & $7.911^{* * *}$ \\
\hline dependent on ext. fin. & & $(1.433)$ & & $(1.296)$ \\
\hline & & {$[0.008]$} & & {$[0.007]$} \\
\hline Top $10 \%$ dependent on ext. fin. & & -0.070 & & $-0.072^{* * *}$ \\
\hline & & $(0.013)$ & & $(0.012)$ \\
\hline Top $10 \%$ reliant suppliers & & & -0.012 & -0.013 \\
\hline & & & $(0.012)$ & $(0.012)$ \\
\hline Year*State F.E. & Yes & Yes & No & No \\
\hline$N$ & 4,349 & 4,308 & 4,785 & 4,728 \\
\hline Adj.- $R^{2}$ & 0.138 & 0.146 & 0.058 & 0.059 \\
\hline
\end{tabular}




\section{Table IX \\ County benchmark}

Panel A shows that a trade credit relationship reduces disturbances to sales growth. It shows coefficient estimates of equation (10), in which the dependent variable is sales growth among customers and the supplier shock is computed relative to the county benchmark. Panel B shows that the insurance effect is irrespective of the customer's importance, which suggests no reverse causality. Panel $\mathrm{C}$ shows that the trade credit insurance effect is absent during recession or for cash poor firms or for financially constrained firms. Panel D shows that the trade credit insurance effect is absent in those cases even if controlling for state-year common shocks. Standard errors in parentheses. The figures in square brackets represent the economic effect of the production and trade credit relationships, which is the response in a customer's sales growth to a one standard deviation increase in the shock to all of its suppliers. It is given as the average over all suppliers of: $\left(\phi \frac{\alpha}{n} D_{i j} S D\left[e_{j}\right]\right)$ for the production relationship and by $\left(\eta \beta_{i} \frac{\alpha(1-\alpha)}{n}\left[D W^{\prime} D\right]_{i j} S D\left[e_{j}\right]\right)$ for the trade credit relationship. The sample runs from 1980 to 2004. All regressions include a constant. Significance is denoted by * at the $90 \%$ level, ** at the $95 \%$ level and *** at $99 \%$ level.

\begin{tabular}{|c|c|c|c|c|}
\hline & \multicolumn{4}{|c|}{ Dependent variable: Customers sales growth $(g)$} \\
\hline \multicolumn{5}{|c|}{ Panel A: Trade credit as insurance against supplier's shocks } \\
\hline & \multirow{2}{*}{$\begin{array}{c}\text { Baseline } \\
\text { (1) }\end{array}$} & \multirow{2}{*}{$\begin{array}{l}\text { F.E. } \\
(2)\end{array}$} & \multicolumn{2}{|c|}{ Time varying F.E. } \\
\hline & & & $(3)$ & $(4)$ \\
\hline \multirow[t]{3}{*}{ Production relationship $(\phi)$} & $1.181^{* * *}$ & $1.071^{* * *}$ & $1.051^{* * *}$ & $1.116^{* * *}$ \\
\hline & $(0.071)$ & $(0.078)$ & $(0.088)$ & $(0.073)$ \\
\hline & {$[0.005]$} & {$[0.005]$} & {$[0.004]$} & [0.005] \\
\hline \multirow[t]{3}{*}{ Trade credit relationship $(\eta)$} & $-1.231^{* * *}$ & $-1.405^{* * *}$ & $-0.665^{*}$ & $-1.035^{* * *}$ \\
\hline & $(0.305)$ & $(0.341)$ & $(0.359)$ & $(0.307)$ \\
\hline & {$[-0.001]$} & {$[-0.001]$} & {$[-0.001]$} & {$[-0.001]$} \\
\hline Firm F.E. & No & Yes & No & No \\
\hline Year F.E. & No & Yes & No & No \\
\hline Industry F.E. & No & Yes & No & No \\
\hline State F.E. & No & Yes & No & No \\
\hline Year *Industry F.E. & No & No & Yes & No \\
\hline Year*State F.E. & No & No & No & Yes \\
\hline$N$ & 4,785 & 4,349 & 4,785 & 4,349 \\
\hline $\operatorname{Adj} .-R^{2}$ & 0.054 & 0.357 & 0.142 & 0.133 \\
\hline \multicolumn{5}{|l|}{ Panel B: Customer's importance } \\
\hline & $\begin{array}{c}\text { Low } \beta_{i} \text { among } \\
\text { bottom } 10 \%\end{array}$ & $\begin{array}{l}\text { Production } \\
\text { network only }\end{array}$ & $\begin{array}{l}\text { Constrained } \\
\text { regression }\end{array}$ & $\begin{array}{l}\text { Strategic } \\
\text { customers }\end{array}$ \\
\hline \multirow[t]{3}{*}{$\overline{\text { Production relationship }(\phi)}$} & $1.586^{* * *}$ & $1.109^{* * *}$ & 1.000 & $1.179^{* * *}$ \\
\hline & $(0.350)$ & $(0.069)$ & constrained & $(0.071)$ \\
\hline & {$[0.007]$} & [0.005] & {$[0.004]$} & {$[0.005]$} \\
\hline \multirow[t]{3}{*}{ Trade credit relationship $(\eta)$} & 21.561 & & $-1.038^{* * *}$ & $-1.232 * * *$ \\
\hline & $(27.964)$ & & $(0.296)$ & $(0.305)$ \\
\hline & {$[0.020]$} & & {$[-0.001]$} & {$[-0.001]$} \\
\hline \multirow[t]{2}{*}{ Top $10 \%$ reliant suppliers } & & & & -0.011 \\
\hline & & & & $(0.012)$ \\
\hline F.E. & No & No & No & No \\
\hline$N$ & 489 & 4,785 & 4,785 & 4,785 \\
\hline Adj.- $R^{2}(M S E$ in column (3)) & 0.044 & 0.051 & 0.243 & 0.054 \\
\hline
\end{tabular}


Table IX cont.

\begin{tabular}{|c|c|c|c|c|}
\hline \multirow{2}{*}{ Panel C: Financial constraints } & \multicolumn{4}{|c|}{ Dependent variable: Customers sales growth $(g)$} \\
\hline & \multirow{3}{*}{$\begin{array}{c}\text { Recession } \\
\text { (1) }\end{array}$} & \multirow{3}{*}{$\begin{array}{c}\text { Cash reserves } \\
\qquad(2)\end{array}$} & & \\
\hline+2 & & & \multirow{2}{*}{$\begin{array}{c}\text { Fin. dependence } \\
(3)\end{array}$} & \multirow{2}{*}{$\begin{array}{c}\text { Fin. dependence } \\
\text { in recession } \\
(4)\end{array}$} \\
\hline & & & & \\
\hline \multirow[t]{3}{*}{ Production relationship $(\phi)$} & $1.371^{* * *}$ & $1.118^{* * *}$ & $1.260^{* * *}$ & $1.388^{* * *}$ \\
\hline & $(0.076)$ & $(0.095)$ & $(0.074)$ & $(0.077)$ \\
\hline & {$[0.006]$} & {$[0.005]$} & {$[0.005]$} & {$[0.006]$} \\
\hline \multirow{3}{*}{ Trade credit relationship $(\eta)$} & $-5.144^{* * *}$ & $-4.575^{* * *}$ & $-8.665^{* * *}$ & $-9.989^{* * *}$ \\
\hline & $(0.630)$ & $(0.862)$ & $(1.321)$ & $(1.413)$ \\
\hline & {$[-0.005]$} & {$[-0.004]$} & {$[-0.008]$} & {$[-0.009]$} \\
\hline \multirow[t]{3}{*}{ Trade credit relationship*Recession } & $4.983^{* * *}$ & & & 5.042 \\
\hline & $(0.697)$ & & & $(3.731)$ \\
\hline & {$[0.005]$} & & & {$[0.005]$} \\
\hline \multirow[t]{2}{*}{ Recession } & $-0.031^{* * *}$ & & & $-0.031^{* * *}$ \\
\hline & $(0.009)$ & & & $(0.009)$ \\
\hline \multirow{3}{*}{$\begin{array}{l}\text { Trade credit relationship }{ }^{*} \text { Top } 10 \% \\
\text { dependent on ext. fin. }\end{array}$} & & & $7.779 * * *$ & $5.841^{* * *}$ \\
\hline & & & $(1.339)$ & $(1.493)$ \\
\hline & & & {$[0.007]$} & {$[0.005]$} \\
\hline \multirow[t]{2}{*}{ Top $10 \%$ fin. constrained firms } & & & $-0.071^{* * *}$ & $-0.069^{* * *}$ \\
\hline & & & $(0.012)$ & $(0.012)$ \\
\hline Trade credit relationship*Recession & & & & -1.015 \\
\hline \multirow[t]{2}{*}{ *Top $10 \%$ dependent on ext. fin. } & & & & $(3.870)$ \\
\hline & & & & {$[-0.001]$} \\
\hline Trade credit relationship*Bottom $5 \%$ & & $71.442^{* * *}$ & & \\
\hline \multirow[t]{2}{*}{ cash poor firms } & & $(20.701)$ & & \\
\hline & & {$[0.066]$} & & \\
\hline \multirow[t]{2}{*}{ Bottom $5 \%$ cash poor firms } & & $0.035^{* *}$ & & \\
\hline & & $(0.016)$ & & \\
\hline F.E. & No & No & No & No \\
\hline$N$ & 4,785 & 3,245 & 4,728 & 4,728 \\
\hline Adj.- $R^{2}$ & 0.066 & 0.044 & 0.066 & 0.074 \\
\hline \multicolumn{5}{|c|}{$\overline{\text { Panel D: Financial constraints - robustness }}$} \\
\hline & \multicolumn{2}{|c|}{ Time varying F.E. } & \multicolumn{2}{|c|}{ Strategic customers } \\
\hline & Recession & Fin. dependence & Recession & Fin. dependence \\
\hline \multirow[t]{3}{*}{ Production relationship $(\phi)$} & $1.293^{* * *}$ & $1.176^{* * *}$ & $1.370^{* * *}$ & $1.259^{* * *}$ \\
\hline & $(0.077)$ & $(0.075)$ & $(0.076)$ & $(0.074)$ \\
\hline & {$[0.006]$} & {$[0.005]$} & {$[0.006]$} & {$[0.005]$} \\
\hline Trade credit relationship $(\eta)$ & $-4.840 * * *$ & $-8.937 * * *$ & $-5.147 * * *$ & $-8.674^{* * *}$ \\
\hline & $(0.659)$ & $(1.485)$ & $(0.630)$ & $(1.321)$ \\
\hline & {$[-0.004]$} & {$[-0.008]$} & {$[-0.005]$} & {$[-0.008]$} \\
\hline Trade credit relationship*Recession & $4.712^{* * *}$ & & $4.984^{* * *}$ & \\
\hline & $(0.723)$ & & $(0.697)$ & \\
\hline & {$[0.004]$} & & {$[0.005]$} & \\
\hline Recession & 0.176 & & $-0.031 * * *$ & \\
\hline & $(0.460)$ & & $(0.009)$ & \\
\hline Trade credit relationship*Top $10 \%$ & & $8.205^{* * *}$ & & $7.786^{* * *}$ \\
\hline dependent on ext. fin. & & $(1.501)$ & & $(1.339)$ \\
\hline & & {$[0.008]$} & & {$[0.007]$} \\
\hline Top $10 \%$ dependent on ext. fin. & & -0.0693 & & $-0.071^{* * *}$ \\
\hline & & $(0.013)$ & & $(0.012)$ \\
\hline Top $10 \%$ reliant suppliers & & & -0.011 & -0.012 \\
\hline & & & $(0.012)$ & $(0.012)$ \\
\hline Year*State F.E. & Yes & Yes & No & No \\
\hline$N$ & 4,349 & 4,308 & 4,785 & 4,728 \\
\hline Adj.- $R^{2}$ & 0.143 & 0.150 & 0.066 & 0.066 \\
\hline
\end{tabular}

